DOI: http://dx.doi.org/10.22201/iie.18703062e.2000.76.1898

HELIA EMMA BONILLA REYNA

INSTITUTO DE INVESTIGACIONES ESTÉTICAS, UNAM

\title{
Joaquín Giménez y El Tío Norilla
}

E

L Tío N ONILLA ES un periódico de formato pequeño² que se publicó entre i849 y I85o en su primera y segunda épocas. Junto con El Calavera y D on Bullebulle, publicados ambos en 1847,3 es uno de los periódicos mexicanos más tempranos que se conocen en que se haya hecho uso abundante de la caricatura; por ello, y porque sólo se le conceden menciones muy breves en los estudios sobre este género, ${ }^{4}$ vale la pena acercarse a sus imágenes, contextualizándolas en el resto de la publicación, y también en los sucesos de la época.

I. D ebo agradecer sus útiles comentarios al maestro Fausto Ramírez, además de su gran estímulo. Aunque casi concluido desde i998, es hasta ahora cuando este trabajo se ha completado gracias a mi participación en el Seminario sobre Política e Intereses en el M éxico Independiente, que dirige el doctor M iguel Soto en la Facultad de Filosofía y Letras de la U niversidad $\mathrm{N}$ acional Autónoma de M éxico; a él debo agradecerle el haberme permitido presentar el trabajo en dicho seminario $y$, desde luego, las acertadas observaciones que ahí se hicieron al respecto.

2. Mide $22 X_{15} \mathrm{~cm}$.

3. Periódicos como D on Simplicio o El Siglo Diez y N ueve publicaron caricaturas sólo ocasionalmente. En cuanto a El gallo pitagórico, se vendió por entregas y como libro, es decir, fuera del formato del periódico (también se obsequió a los suscriptores de El Republicano y a los del M emorial H istórico).

4. Joyce Wadell Bailey y Ricardo Pérez Escamilla son algunos de los escasos autores que lo han comentado someramente en sus respectivos trabajos: Joyce W adell Bailey, "T he Penny Press", en Ron Tyler, Posada's M exico, W ashington, W ashington Library of Congress, 1979, pp. 9I-92, y Ricardo Pérez Escamilla, “Arriba el telón. Los litógrafos mexicanos, vanguardia artística y política del siglo xix", en M useo N acional de Arte, N ación de imágenes La litografía mexicana de siglo XIX, M éxico, Amigos del M useo N acional de Arte-Instituto $\mathrm{N}$ acional de $\mathrm{Be}$ Ilas Artes-G rupo ICA-Banamex-Elek, M oreno Valle y Asociados, I994, p. 28. Dos trabajos panorámicos recientes en que se aborda la inserción de EI Tío N onilla en la historia de la cari- 
DOI: http://dx.doi.org/10.22201/iie.18703062e.2000.76.1898

I80

HELIA EMMA BONILLA REYNA

Joaquín Giménez, viajero

El español Joaquín Giménez fue director, caricaturista y redactor en jefe de El Tío N onilla; escritor de carácter inquieto, estuvo involucrado, como muchos intelectuales de la época, en la literatura, el periodismo y la política. Cuando a principios de septiembre de i85o el periódico mexicano La Espada de $D$ amocles lo acusó entre otras cosas de ser un redactor de nuevo cuño, Giménez declaró haber sufrido persecuciones, destierros, haber expuesto la vida y defendido la república en su país; afirmó pertenecer a una distinguida familia, haber pasado sus primeros años en la última guerra civil, en la que llegó a ser capitán de caballería; haber desempeñado puestos de importancia en el gobierno de $M$ adrid, y con la marcha de éste, dimitir en 1847.5 Trabajaría entonces como redactor, a un tiempo, en el periódico político El Siglo,

catura y la gráfica satírica del siglo xix son: Rafael Barajas (EI Fisgón), La historia de un país en caricatura: Caricatura mexicana de combate: $1829-1872, \mathrm{M}$ éxico, Consejo $\mathrm{N}$ acional para la $\mathrm{Cul}$ tura y las Artes, 2000, 374 pp., y H elia Emma Bonilla Reyna, "La gráfica satírica y los proyectos políticos de nación: (I808-I857)", en M useo N acional de Arte, Los pinceles de la historia: de la patria criolla a la nación mexicana: I750-I860, M éxico, M useo N acional de ArteU niversidad $\mathrm{N}$ acional Autónoma de M éxico, Instituto de Investigaciones Estéticas, 2000, pp. 170-187.

5. La pérdida de las colonias causó a España una crisis económica y política de la cual tardaría más de un siglo en recuperarse. La inestabilidad política fue profunda; a la muerte de Fernando VII se desata la guerra carlista por la sucesión del trono, que duraría de i833 a 1839, y en la que los liberales apoyaron a I sabel II, la hija del rey, y los carlistas a don Carlos, hermano de aquél. La guerra tuvo distintas etapas (la más conflictiva va de la primavera de I835 al otoño de i837), y no se sabe a partir de qué momento intervino en ella Joaquín G iménez. La victoria fue finalmente para los liberales; sin embargo, el antagonismo de las dos facciones que los componían, progresistas y moderados, creó pugnas al interior. En principio los progresistas quedaron en el poder, siendo encabezados por el general Espartero, pero éste fue reemplazado por el general $\mathrm{N}$ arváez en I844, iniciando con su gobierno la llamada década de los moderados. N o obstante, la situación continuó inestable debido a la escasa homogeneidad de los propios moderados, y N arváez dimitió en febrero de i846. D e ahí hasta su vuelta al poder en octubre de 1847 hubo cinco gobiernos, y es posible que Giménez haya colaborado con el de Pacheco, que duró de marzo a agosto de i847. En i848 N arváez enfrenta y derrota una serie de conspiraciones y movimientos armados de progresistas (durante la primera parte del año, con desórdenes en la ciudad de Madrid el 26 de marzo y el 7 de mayo), republicanos revolucionarios (en verano) y carlistas (en otoño). Es posible que la expulsión de G iménez esté vinculada con estos sucesos; según sus propias palabras, vivía como periodista justamente en $M$ adrid, y quizá haya participado en la conspiración de los progresistas, puesto que en julio ya estaba encarcelado, y días después fue expulsado de España. Vicente Palacio Atard, La España del siglo xıx: $1808-1898$, M adrid, Espasa-C alpe, 1978, 668 pp. 
en la Gaceta de Teatros y en la Revista Científica y Literaria de M adrid, que fue una de las publicaciones literarias de mayor aceptación. Su maestro de literatura fue el célebre crítico literario $\mathrm{M}$ anuel $\mathrm{C}$ añete. ${ }^{6} \mathrm{Al}$ presentar sus "títulos literarios", cómo él los Ilama, el español cita un artículo publicado en El N acional de Cádiz, de fecha 7 de julio de 1848 , en el que se afirma que el señor Giménez (o el tío N onilla, que era el seudónimo que ya entonces utilizaba) por motivos políticos se encontraba en ese momento encarcelado en el castillo de San Sebastián, en donde escribía una preciosa novela titulada Cien cartas á Constanza, la cual seguramente sería de mérito dados sus antecedentes literarios, pues había publicado ya en $\mathrm{M}$ adrid su $\mathrm{H}$ istoria política de los ministros españoles de $1843 .^{7}$

Tres días después, según él mismo cuenta, el io de julio de ı848, luego de haberse despedido con tristeza de sus padres, parientes y amigos, partió de Cádiz hacia América (desterrado), ${ }^{8}$ y es posible seguirle la pista gracias al primer tomo, quizá el único, de una obra suya titulada "La H abana por dentro", manuscrita y probablemente inédita. ${ }^{9}$ En ella se revela un hombre inserto en las inquietudes viajeras de su época, aunque muy a su manera, pues su sentido del humor siempre está presente. Giménez se encontraba en el inicio de lo que creía un viaje "por países lejanos y enteramente desconocidos", io y en este sentido imaginaba América como algo exótico e ignoto que había que desen-

6. El erudito sevillano $M$ anuel $C$ añete (I822-189I) fue un conocido hombre de letras en su época; escribió poesía y teatro, pero sobre todo destacó en la oratoria parlamentaria y en la crítica literaria; hizo numerosos estudios sobre literatura española y latinoamericana, entre los que se encuentra T eatro español del siglo XVI y Escritores españoles e hispanoamericanos, publicados respectivamente en 1855 y en 1882 . Emiliano D íez-Echarri et al., $\mathrm{H}$ istoria general de la lite ratura española e hispanoamericana, 2a. ed., M adrid, Aguilar, I979, pp. 742, 983, I0I7 y II59, y Ángel Balbuena Prat, H istoria de la literatura española, 8a. ed., Barcelona, G ustavo Gili, I974, t. I, p. 8ro.

7. "Al autor de “El Ensayo'”, en El Tío N onilla, M éxico, 26 de agosto de i849, t. I, suplemento del núm. 2, sin número de página, y "A los redactores de La Espada de Damocles", en El Tío... op. cit., sin fecha, t. II, suplemento del núm. 2, p. 4.

8. El M onitor Republicano afirmó, después de que Giménez fue expulsado de M éxico a fines de i849, que el ministro español no lo había reconocido como súbdito de España y que había sido desnaturalizado en su primitivo país. "G acetilla", en EI M onitor Republicano, M éxico, I3 de diciembre de 1849 , año 5, núm. 1675, p. 4.

9. Este manuscrito pertenece al caricaturista Rafael Barajas, El Fisgón, a quien debo agradecer la generosidad de permitirme consultarlo.

ı. Joaquín Giménez, "La H abana por dentro", manuscrito concluido en La H abana el ${ }^{\circ}$ de junio de 1849, p. 7. 
trañar. Prometía al lector hacer descripciones de cuanto viera, e intercalar en ellas, para ilustrarlas mejor, excelentes grabados de trajes, plantas, máquinas, edificios, monedas, carruajes, animales, vistas de las poblaciones que visitara y todo aquello que le pareciera pintoresco y digno de darse a conocer. Al llegar a Tenerife, por ejemplo, desembarcó e hizo una descripción geográfica y dibujó una vista de la isla, pero como no encontró nada novedoso, según narra él mismo, se lanzó otra vez al agua en busca de cosas distintas; quería hacer llegar al lector lo que no conocía o lo que le había llegado envuelto en oscuridades para mostrárselo desnudo. II Se manifiesta en sus palabras una actitud romántica y una pretensión cientificista, características de algunos de los europeos que vinieron a América durante el siglo xix.

El primer lugar de América que conoce es Puerto Rico, y aunque desembarca ahí y hace algunas descripciones generales, no le interesa quedarse. Prosigue su viaje a Cuba, entonces el "último tesoro español", donde permanecería aproximadamente un año; ahí empieza a redactar el i7 de agosto de 1848 el manuscrito de "La H abana por dentro", que se enfoca sobre la vida de este país. Sin embargo, Giménez lo lleva a cabo de manera peculiar, porque además de que su vena profundamente satírica nunca le abandona, aprovecha cualquier situación para deslizar comentarios críticos al gobierno español y a los habitantes de la isla.

D esde un principio hace la narración en primera persona, intercalando diálogos; va narrando de manera irónica los percances del viaje. Un personaje ficticio le acompaña: Nonilla, a quien llama a menudo tío (expresión española). Dice Giménez que sería triste estar solo en estas tierras, por ello "tomé en mi compañía al amigo Nonilla, hombre que si bien me proporciona continuos disgustos con sus sandeces, no dejará de darme así algunos ratos de entretenimiento y por cuya sola razón sufro y escribiré sus impertinencias"; aclara que aunque hace poco que anda con él, ya le conoce a fondo, y teme que cause al lector algún disgusto por su carácter francote y bonachón, pues dice lo que siente sin reflexionar. ${ }^{12}$ En este escrito Giménez y N onilla son dos personajes independientes: uno es el amo, generalmente circunspecto, y el otro el criado franco, bueno y tonto. ${ }^{13}$ En el carácter de N o-

II. Ibidem, p. 2 I.

I2. Ibidem, p. 8.

I3. Giménez parece haber echado mano de un recurso bastante usual entre los escritores románticos: el desdoblamiento del yo. Así, N onilla es una suerte de sosia o proyección de algunos rasgos del propio Giménez. Acaso el desdoblamiento creativo más célebre de la época 
nilla se acentúan las intenciones de hacer reír, pues a menudo formula preguntas bobas, y de denunciar las injusticias y errores de la corona española que ha maltratado a Giménez. Se queja, por ejemplo, de haber visto que golpeaban a un esclavo negro, siendo que se ha proclamado ya la libertad en todo el mundo; ${ }^{14}$ Giménez le dice que se conduela a solas, que ahora deben verlo y saberlo todo, para luego decírselo a los hermanos lectores; N onilla se resigna a callar con tal de contar un día las bribonadas que ahí suceden. ${ }^{\text {Is }}$

Como muchos de los libros de viajes pintorescos, el manuscrito iba acompañado originalmente de 32 láminas, lo que es posible saber gracias al índice de ilustraciones. Pero la mayoría fue arrancada y sólo se conservan cinco. Giménez dibujó a pluma cuatro de las que se conservan: una Vista de SantaCruz de Tenerife, una Vista de Puerto-Rico, una de la M oneda M acuquina de Puerto-Rico y una Palma indiana (que aunque él la numera como lámina, es más bien un apunte poco logrado). Están realizadas cuidadosamente, y las dos vistas muestran un juego de entramados de líneas y una variedad tonal interesante, aunque es evidente que fueron hechas por un aficionado; son sintéticas en la forma y se alejan de la destreza y realismo que podría encontrarse, por ejemplo, en el trabajo de los artistas viajeros. La quinta es una litografía titulada Jardines de Tacón, que Giménez debió recortar de otra publicación y que anexó a su escrito. Como se verá adelante, el escritor recurrió constantemente a imágenes de publicaciones preexistentes para ilustrar sus propios textos, lo que es comprensible porque su oficio no fue propiamente el de dibujante, y no siempre le satisfacían sus intentos en este arte. Encontramos en el manuscrito, por ejemplo, dos dibujos fallidos que él mismo tachó.

sea el de los personajes de Eusebio y Florestán, que habitaban en el yo de Robert Schuman, tanto en su aspecto de compositor como de crítico musical. Por lo demás, el tema del "doble" recorre la literatura del siglo xix. Además, era un recurso muy utilizado en la literatura satírica la creación de un personaje con quien dialogar y, de esta manera, dar pie a numerosas observaciones críticas de la sociedad contemporánea. Pensemos, para el caso mexicano, en El gallo pitagórico de Juan Bautista M orales.

I4. Giménez era impreciso al hacer esta aseveración. En efecto, ya en muchos de los países europeos habían fructificado las ideas abolicionistas, derivadas de las ideas filosóficas dieciochescas. En España, por ejemplo, la esclavitud se abolió definitivamente en ı837, permitiendo, sin embargo, por razones económicas, su existencia en Cuba, y también en Puerto Rico. En Estados U nidos sería hasta la guerra de secesión, entre i86o y i865, cuando esta situación se resolvería de manera definitiva en todo el territorio. M . Cowley y D aniel P. M annix, H istoria de la trata de negros, M adrid, Alianza, 1968, 28I pp.

I5. Giménez, "La H abana... ," op. cit., pp.72-73. 
I84 HELIA EMMA BONILLA REYNA

En general, Giménez cumplió con lo prometido en cuanto a la temática de las ilustraciones, salvo que no hizo ninguna sobre trajes. Se trataba sobre todo de vistas de lugares y monumentos de La H abana y de Cuba en general (el Gran Teatro de Tacón, Puente de M arianas, Alameda de Paulas, etcétera), así como de algunas sobre flora (U ba salvaje) y fauna (Cucullos y Aguaceritos).

El texto es muy rico en cuanto a la descripción de la vida y las costumbres de la época: habla de la "venduta pública", de los bailes de negros, describe la venta de una esclava, el carnaval de La H abana, los Jardines de Tacón, la Semana Santa en La H abana, el castillo de esa ciudad, etcétera. D escribe satíricamente a los habaneros y habaneras (a éstas las Ilama las irresistibles, y aclara que así se califican ellas mismas); habla de un método para enamorarlas, y cuando llega al apartado Sociedad de La Habana, dice: "D e esto estamos excusados de hablar porque en aquel país se carece casi totalmente de ella." 16

Explica su resentimiento hacia los cubanos y, de manera implícita, su transición de viajero a periodista crítico en América. En todos lados, dice, se cree que el extranjero es el que sabe más y por ello le ofrecieron la redacción del periódico El Avisador del Comercio, labor que inició el $\mathrm{I}^{0}$ de septiembre de i848. D ebido a esta razón su estancia en la isla se prolongó más de lo que esperaba, y aunque en principio dicho cargo le proporcionó una ocupación y una posición más ventajosa que la de paseante, según él mismo aclara, al final le resultó muy desagradable. Tres cosas lo molestaron: la primera fue la censura, que él juzgaba superficial; la segunda, que en La H abana los directores de periódicos se veían obligados a publicar textos espantosos, dado que ahí todos los hombres eran poetas y se suscribían a un periódico pensando que tenían derecho a que se les publicara; y la tercera, y probablemente la que le atrajo dificultades y recriminaciones, fue que, según él, en La H abana el periodista no podía criticar ninguno de los vicios o costumbres de la sociedad, y debía cuidar que ni por asomo se ridiculizara a un individuo 0 cosa del país, so pena de perder la suscripción. Por ello un hombre digno, dice Giménez, no podía ser periodista en La H abana por largo tiempo.

Tal vez el escritor expresó alguna ironía respecto a las mujeres que incomodó al público cubano, pues inicia el apartado $\mathrm{M}$ i vida de periodista ${ }^{17}$ quejándose de que en $\mathrm{La} \mathrm{H}$ abana se las idolatre y de que los periódicos tengan que adularlas, Ilamándolas hermosas y virtuosas; las mujeres hacen que los

I6. Ibidem, p. I84.

I7. I bidem, p. I25. 
maridos retiren su suscripción de un periódico que habla poco de ellas, y tildan de tonto a su redactor. La hipótesis anterior parece confirmarse porque meses después, ya en M éxico, publicó buen número de textos en que su misoginia literaria se puso de manifiesto. En una Sátira que dedicó a las necias que pretendían casarse merced a sus afeites y composturas, decía que odiaba tener que establecer relaciones con las mujeres; aclaraba, además, que había escrito dicha sátira en La H abana, y que aquí continuaría publicando otros escritos para hacer polémica al respecto. Aclaraba que de ellos sus lindas lectoras tendrían que salir airosas, quizá previniendo una reacción como la que en Cuba había causado. ${ }^{18}$

A pesar de que por lo anterior Giménez pensó en abandonar casi desde el principio el diario mencionado, sus amigos supuestamente le hicieron desistir, por lo que continuó trabajando en él, pero al fin, exasperado, y a pesar de los ruegos, renunció en enero de i849. N o obstante su descontento, Giménez estuvo dirigiendo al mismo tiempo La Abeja Literaria. ${ }^{19}$

De Cuba - dice él posteriormente- "nos arrojaron sucesos que nos honran", ${ }^{20}$ pero no aclara cuáles fueron ni si tuvieron relación con sus disgustos anteriores, y se desconoce qué actividades realizó desde su renuncia como redactor hasta su salida de aquel país. El manuscrito, que pretendía ser el primer tomo de su obra de viajes, trae como fecha final el ${ }^{0}$ de junio de I849, en La H abana.

\section{Joaquín Giménez en M éxico}

No transcurrió mucho tiempo para que el hiperactivo Giménez apareciera en M éxico; por ahora no es posible saber por qué decidió venir, pero lo cierto es que, según sus palabras, tanto en Europa como en Cuba había establecido contacto con mexicanos "respetables", ${ }^{21}$ y quizá fueron ellos quienes le pro-

I8. "Sátira", en El Tío..., op. cit., in de agosto de I849, t. I, núm. I, p. 9.

I9. "La Espada de Damocles", en El Tío..., op. cit., 26 de agosto de I849, t. II, suplemento del núm. 2, p. 4.

20. "Al autor de 'El Ensayo'”, en El Tío..., op. cit., 26 de agosto de 1849 , t. I, suplemento del núm. 2, sin número de páginas.

2I. "Al M onitor Republicano", en El U niversal, 7 de agosto de 1849 , núm. 265, p. 2. H ay que recordar que Cuba era un punto en el camino a Turbaco, lugar donde se exilió Santa Anna, y en donde sus partidarios llegaron a visitarlo. 
pusieron trabajar aquí. El 4 de agosto de 1849 El M onitor Republicano comentaba ya, negativamente, el anuncio con que se publicitó la salida a la luz de El Tío Nonilla; ${ }^{22}$ el 25 de agosto volvía a ocuparse de Giménez para señalar que su pieza teatral Un yanqui ó el honor de una pulquera había sido censurada, ${ }^{23}$ lo cual implica que el escritor trabajaba intensamente. Al defenderse, Giménez decía que el hecho de que su obra hubiese sido prohibida y censurada no significaba que fuese mala, y afirmaba también que en la representación de sus otras comedias nunca le habían lanzado cojines, ni se había cerrado el telón a la mitad de ellas (lo que según él sí había ocurrido con las obras del autor del artículo de El M onitor Republicano). ${ }^{24}$

La labor más propia de Giménez fue la literaria, y no la de dibujante, pues mientras presenta sus "títulos literarios" no cuenta nunca si realizó caricaturas antes, seguramente porque no las hizo o si las hizo no les concedió importancia, y ni siquiera menciona su afición al dibujo, la cual ya se había plasmado en su libro de viajes. Giménez fue poco diestro como ilustrador, y debió estar consciente de ello. Por otra parte, es sólo en la segunda época cuando El Tío Nonilla se acompaña de abundantes imágenes, en principio grabados provenientes de otras publicaciones; en la primera época, el periódico no se ilustró. Sin embargo, es entonces cuando realiza sus primeras litografías en M éxico, que publicó en una obra independiente titulada Ensayos magnéticos de el tío N onilla, de la cual se habla adelante.

La literatura ocupa buena parte de las páginas de El Tío N onilla, sobre todo en la primera época. Además, el español, en la ciudad de M éxico, volvió a llevar a las tablas otra obra: un sainete titulado El doctor Canuto o Cuatro novios para una, ${ }^{25}$ la cual, dice en un artículo de su periódico en donde se queja de los desórdenes que causa el público, "fue la primera silbada en esta nueva era de silbidos y escándal os". ${ }^{26} \mathrm{~N}$ iega también ser él quien hubiese promovido los alborotos subsecuentes ocurridos en la representación de otras obras, en venganza por la mala representación que se hizo de la suya. ${ }^{27}$

22. "El T ío N onilla”, en El M onitor..., op. cit., 4 de agosto de I849, núm. I544, p. 4.

23. Ibidem, pp. 2-3. Respecto a la obra teatral de Giménez, éste representó también otra obra titulada EI doctor C anuto o Cuatro novios para una. V éase la nota 27.

24. "Al autor de 'El Ensayo'”, en El Tío..., op. cit., 26 de agosto de 1849 , t. i, suplemento del núm. 2 , sin número de páginas.

25. "Beneficios", en El Tí́o..., op. cit., I4 de octubre de I849, t. I, núm. 9, p. I39.

26. "Revolución teatral”, en El Tío..., op. cit., I8 de noviembre de I849, t. I, núm. I4, p. 216.

27. La obra teatral de Giménez en M éxico, según parece, no dejó huella; no encontré ninguna referencia ni a ella ni a su persona en los clásicos estudios sobre la historia del teatro 


\section{Giménez publica El Tío N onilla}

La primera época de El Tío N onilla se inicia el in de agosto de i849, cuando aparece anunciado como periódico político, enredador, chismográfico y de trueno, y concluye con el número 26 , el último que se encuentra en la Hemeroteca Nacional de M éxico, publicado el i7 de febrero de i85o. La segunda época comienza el 29 de agosto de i850 y concluye el 26 de diciembre del mismo año, con el número $17 .{ }^{28}$

Como lo hacían muchos de los periódicos de la época, El Tío Nonilla anunció su publicación con un prospecto, que en parte decía así: "unos cuantos holgazanes se ocuparán de escudriñar las proezas de los gobernantes, los acontecimientos más recónditos de nuestra sociedad, los chismes y diretes de las mugeres, las aventuras de los hombres mas precavidos, los lances amorosos, \& C., \& c."29 Esto le ganó como enemigo inmediato a El M onitor Republicano, periódico que apoyaba al gobierno (entonces en manos del partido moderado), pues en apariencia le molestó el tono irreverente del anuncio, por lo que el 4 y el 7 de agosto de i849 señaló que seguramente el gobierno prohibiría su publicación y le aplicaría una ley contra extranjeros perniciosos, ya que amenazaba entrometerse en la vida privada de las personas..$^{\circ}$ Sin embargo, es posible que en realidad la antipatía se debiera a que El M onitor Republicano conociese de antemano la postura santanista de El Tío N onilla. Tres días después, Joaquín Giménez contestó en tono furibundo desde EI U niversal, periódico conservador y enemigo de EI M onitor Republi-

en M éxico de O lavarría y Ferrari y de Reyes de la M aza. Enrique O lavarría y Ferrari, Reseña histórica del teatro en M éxico, I538-I9II, za. ed. ilustrada y puesta al día de I9II a I96I, M éxico, Porrúa, I96I, t. I, 492 pp.; y Luis Reyes de la M aza, El teatro en M éxico en la época de Santa Anna, M éxico, U niversidad N acional Autónoma de M éxico, Instituto de Investigaciones Estéticas, 1972, t. I (1840-1850), 597 pp. (Estudios y Fuentes del Arte en M éxico, xxx).

28. Bailey, op. cit., p. 9I, señala que EI Tío N onilla fue impreso en el mismo lugar que el periódico EI Calavera: calle de C hiquis, en la Tipo-Litografía de $\mathrm{N}$ avarro. Cabe puntualizar, no obstante, que a lo largo de su publicación, salió de distintas imprentas: durante su primera época, de La Voz de la Religión (calle de San José el Real núm. I3); en su segunda época, los tres primeros números salieron de la imprenta de Vicente $\mathrm{G}$ arcía Torres, y el resto de la de Juan R. N avarro. Además, algunos de los suplementos salieron de otros negocios, como por ejemplo el del número 4 , fechado el 28 de septiembre de 1850 , el cual salió de la calle de las Escalerillas núm. 2, y fue impreso por $M$ anuel $F$. Redondas.

29. "EI Tío N onilla”, en El M onitor..., op. cit., 4 de agosto de I849, núm. I544, p. 4.

30. Ibidem, y “D esvergüenza”, en El M onitor..., op. cit., 8 de agosto de I849, núm. I548, p. 4. 
cano, Ilamándole "papelucho... de lenguaje verdulario", y diciéndole que, siendo él persona educada, era capaz de cumplir lo ofrecido sin perjudicar la honra de ningún individuo; que no había ninguna ley que prohibiera escribir a los extranjeros; que aunque la publicación llevaría el seudónimo que él utilizaba en sus escritos desde hacía al gún tiempo, y a pesar de que él se había ofrecido a escribir en ella y hasta a dirigirla, sus verdaderos autores y dueños eran nacidos, bautizados, criados y aun casados y enviudados en M éxico (¿se referiría acaso a Santa Anna, quien estaba entonces en el exilio?). El Tío N onilla decía contestar de paso a El Siglo Diez y Nueve, periódico que también lo había atacado, así como a quien fuese necesario. ${ }^{31}$

El Tío N onilla surgió dentro de una contienda periodística en la que los provocativos, violentos y constantes ataques reflejaban la lucha por el poder entre los distintos partidos y facciones políticas: conservadores, moderados, puros, santanistas, almontistas, etcétera. Giménez entró en la pugna, tomando la bandera de oposición al gobierno moderado del presidente José joaquín de H errera bajo una encubierta postura santanista, como se verá adelante, y sosteniendo agresivos altercados con sus opositores. Cabe mencionar que en este sentido El Tío N onilla es en su segunda época, por las ilustraciones que lo acompañan, un antecedente de los periódicos con caricaturas que en décadas posteriores sirvieron de apoyo a las campañas electorales.

En un plazo brevísimo de dos meses, Giménez había concluido su texto de viajes en La H abana, había escrito y representado una obra de teatro, y se había anunciado como periodista en M éxico. D urante la primera época de El Tío Nonilla, Giménez puso su experiencia al servicio de los "verdaderos autores y dueños" del periódico, cuya identidad ha quedado en el anonimato, al igual que la de los otros colaboradores. ${ }^{32}$ Sin embargo, es posible señalar que fueron santanistas, y que en la segunda época de la publicación Giménez rompió con ellos.

El español bautizó al periódico con su seudónimo, y en él, como en su libro de viajes, el personaje del tío $\mathrm{N}$ onilla reaparece, pero no es ya el criado bobalicón y bueno sino el propio Giménez, con cuyo sobrenombre fue

3I. "Al M onitor Republicano", en El U niversal, M éxico, 7 de agosto de ı849, t. II, núm. 265 , p. 2.

32. "Interesante a los desesperados y pobres de espíritu", en EI T ío..., op. cit., 23 de septiembre de 1849 , t. I, núm. 6, p. 94. En este artículo da alguna pista sobre quienes fueron los otros redactores en la primera época, pues está firmado, al parecer, con los nombres de pila, en diminutivo, de los redactores, que además de J oaquinito son Pepito y Agustinito. 
conocido en M éxico. Los temas del periódico son variados, como se anunciaba en el prospecto y bajo los sucesivos encabezados de la publicación en sus dos épocas. Aunque ocasionalmente se entremezclan, los asuntos son: la política, la literatura (novelas, leyendas y poemas, casi todas obras de románticos españoles), 33 lo que él Ilama la chismografía (y que suele ser crítica de costumbres), chistes, tradiciones, y también la vida del teatro mexicano.

Todo ello se trata en prosa y en verso, mediante cuentos, epigramas 0 chistes. Y si bien en ocasiones el tono es solemne, como ocurre en las novelas o relatos por entregas, en algunos poemas de tono romántico y en muchos de los artículos de política (en los que de cualquier manera se cuelan comentarios chuscos e irónicos), a lo largo de las páginas de El Tío N onilla predomina el corrosivo humor de Joaquín Giménez.

Aunque la caricatura como imagen visual no aparece en la primera época, sí lo hace como imagen literaria en forma constante, y el mismo Giménez lo dice explícitamente de esa manera, como se aprecia en el artículo titulado "La suegra", publicado en el número 7 del 30 de septiembre de i849. En él afirma que va "emborronar" una caricatura o tipo que ha pasado inadvertido en Los españoles pintados por sí mismos y en Les français peints par eux mêmes, que es precisamente el de la suegra. D espués de hablar en tono irónico de sus susceptibilidades y de los derechos que se toma, afirma: "La suegra es un tipo escepcional", tiene "las mismas propensiones en todas partes", en ella "no cabe lo ecsótico ni indígena: la suegra es un ser cosmopolita", "un ejército de suegras debe ser invulnerable, inconquistable" ${ }^{34}$

A través de los escritos humorísticos del El Tío Nonilla es posible discernir actitudes recurrentes, ya sea porque forman parte del carácter del autor, ya porque las considera recursos adecuados para lograr hacer reír a su público: la misoginia, la aversión al matrimonio y a los hijos, a los frailes y monarquistas, a la ridiculez de los enamorados o de los vanidosos y elegantes, a la fealdad y la vejez. Esto ocurre, por ejemplo, con las imágenes que

33. En la primera época se publicó por entregas la novela Trampas legales, del español Tomás Rodríguez Rubí; en la segunda época se publicó D oña Blanca de N avarra (aunque no se aclara quien es el autor, se trata de Francisco $\mathrm{N}$ avarro Villoslada), El page de doña Blanca de J osé C asanova (el otro redactor de El Tío N onilla en la segunda época), U n nuevo J osé (leyenda española), El castellano viejo, de Larra. Entre los textos literarios hay también al gunos poemas que cuando no son chuscos son de un romanticismo lánguido. Algunos de éstos fueron escritos por el mismo Giménez.

34. "La suegra”, en El Tío..., op. cit., 30 de septiembre de ı849, t. i, núm. 7, pp. ıo4-ıo6. 


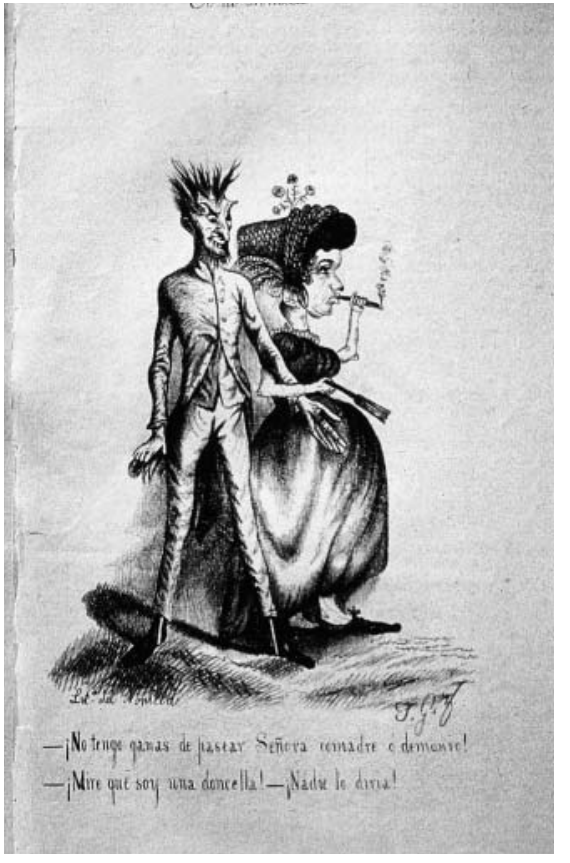

Figura i. J oaquín Giménez, segunda imagen que ilustra el artículo "M i comadre", en El Tío N onilla, 5 de diciembre de 1850 , t. II, núm. I4, entre las pp. 212 y 213 (su texto empieza: "- N o tengo ganas de pasear Señora comadre ó demonio! / - M ire que soy una doncella! - N adie lo diria!), II x 9.I $\mathrm{cm}$, Fondo Reservado de la $\mathrm{H}$ emeroteca $\mathrm{N}$ acional de $\mathrm{M}$ éxico. Foto: $\mathrm{H}$ elia Emma Bonilla Reyna (HEBR).

ilustran un cuento titulado $\mathrm{M}$ i comadre, que apareció el 5 de diciembre de I85o, en el que supuestamente Gerónimo, un amigo del Tío N onilla, lo invita para que bautice a su hijo y lo lleva a conocerlo. El Tío dice entonces: en una cama "ví una especie de lechuza descarnada y asquerosa que Gerónimo me aseguró bajo su palabra ser su muger, la cual daba un pecho semejante a una tripa, á un viviente que más parecía gato que otra cosa"; luego Gerónimo lo lleva a conocer a su comadre, la mujer que sería la madrina del niño, y que según el Tío, parecía un demonio. Ésta, en la charla, lo toma del brazo para pasear (figura I), lo cual le disgusta muchísimo a él, pues todo mundo se ríe al verlo con semejante adefesio; el Tío le manifiesta a la comadre que detesta a las mujeres, y ella le responde que siendo mujer no debería hacerle ese comentario; él replica que no lo parece. Pelean. ${ }^{35}$

En la imagen, la comadre-demonio aparece fumando, lo cual no ocurre en el texto; para el caricaturista, es decir Giménez, éste es un rasgo que la afea aún más. Esta aversión al cigarrillo ya la había expresado El Tío N onilla 
en un "Pensamiento suelto" publicado antes, en el que manifestaba: "M ientras los hombres fumen en los teatros y las mugeres en cualquiera parte, la sociedad mexicana no será culta..."; firma El enemigo del H umo. ${ }^{36}$

Ésta es, por otra parte, la única imagen en que Giménez representa al personaje del Tío N onilla, y que, como muchas otras hechas por él, fue copiada de una realizada por el ilustrador romántico Tony Johannot ${ }^{37}$ para el libro francés Voyage où il vous plaira, publicado en ı843, y cuyo texto fue escrito por M usset. H ay, por otra parte, un paralelo interesante, pues el dibujo del personaje que representaba originalmente al compañero de viaje del protagonista de la historia de M usset $3^{3}$ fue el que sirvió de modelo para el Tío N onilla, quien era a su vez el compañero de viaje de Giménez en "La H abana por dentro".

En El Tío N onilla se describe, de manera caricaturesca, la improvisación de los cómicos de la legua y sus tropiezos en las representaciones. Dice el autor que no sabe por qué, pero muchos de los actores son costureras o bordadoras, con sus aprendices y oficiales de sastre; piensa que esto quizá se deba a que no encuentran trabajo o están mal pagados. La compañía no puede salir de gira porque la actriz principal está endeudada con el bodeguero; el nombre de la función se anuncia improvisadamente con un texto manuscrito. M ientras la primera actriz pega oropeles en su túnica, el primer galán sale a pasos agigantados y declama con voz rotunda a la vez que, en plena escena, recorta su calzado para adecuarlo a la época; tras él, los actores discuten quién hará el carcelero y quién sacará las sillas y las luces; el apuntador no encuentra la comedia y no tiene otro ejemplar. Al final, tras la caída de una parte de la escenografía, y de que a la actriz se le rompe el vestido, la gente avienta papas y grita. ${ }^{39}$

36. "Pensamiento suelto", en El Tío..., op. cit., 9 de septiembre de i849, t. I, núm. 4, pp. 49-50.

37. Célebre dibujante romántico, el francés T ony Johannot (1803-1852) ilustró obras de Goethe, Lafontaine, Lamartine, M olière, Perrault, Prévost, Rousseau, Sand, Vigny, Sue, Balzac, Victor H ugo y el Q uijote de Cervantes.

38. El maestro Fausto Ramírez me hizo notar que Giménez usó como fuentes las imágenes con que Johannot ilustró el Voyage où il vous plaira. Tomé como referencia la traducción en español: Alfred M usset, Viaje a donde se os antoje, Barcelona, H esperus, 1987, I78 pp. Por lo que se refiere a la imagen de la que Giménez tomó el personaje para representar a $\mathrm{N}$ onilla, véase la página 30.

39. "Los cómicos de la legua”, en El Tío..., op. cit., i4 de octubre de I849, t. I, núm. 9, pp. I44-I45. 
192 HELIA EMMA BONILLA REYNA

En cuanto a la chismografía, las historias también son innumerables, y es evidente el público al que se destinan. Dice El Tío N onilla que asiste a las conocidas soirées que ofrecen el ministro de Francia, M r. Levasseur, y su mujer, sólo para poder contarlas a sus lectoras; se burla de la abundante "correspondencia miratoria" de las mujeres, y del enamoramiento como estado ridículo. ${ }^{\circ}$ D entro de la chismografía están las notas indiscretas y chuscas, en las que a la vez hace crítica de costumbres, ridiculizando la vida de diversas personas sin revelar sus nombres, con lo cual cumple lo que había dicho a El $M$ onitor Republicano respecto a que podía escudriñar en los chismes y diretes de las mujeres sin afectar la honra de la gente.

Encontramos también alguna crónica. Se narra, por ejemplo, el desenvolvimiento de un baile concurrido en el pueblo de San Ángel, en las afueras de la capital, que se llevó a cabo en un arreglado salón, con señoritas muy acicaladas; se sirven refrescos, los asistentes dan serenata a las damas; terminan ebrios, refugiándose donde pueden y robando distintos objetos en una fonda. ${ }^{4 \mathrm{O}} \mathrm{O}$ se refiere que gracias a Arbeu, a quien El Tío N onilla llama socarronamente empresario del gas, el Teatro $\mathrm{N}$ acional cuenta por primera vez con alumbrado de gas, que es superior al de aceite, que era el que antes tenía. ${ }^{42}$

Se queja para que las autoridades remedien males que aquejan a los capitalinos; por ejemplo, un rótulo antisombreril en la calle de la Profesa, con el cual dice que se estrellan las cabezas. ${ }^{43} \mathrm{H}$ abla también de una inminente y caricaturesca Revolución femenil, "en la que se defienden intereses tan crecidos como el cabello de las niñas que se maltrata y la economía por tener que limpiar el traje", y que se desatará si las autoridades no riegan la Alameda en las tardes para que no se levante polvo. ${ }^{44}$ Amenaza con ridiculizar a funcionarios o empleados si no cumplen con su deber; por ejemplo, en el número del ir de noviembre de i849 señala que los suscriptores continuamente reciben los ejemplares de EI Tío N onilla manchados por agua o rotos; se dirige a los empleados de correos para que le eviten hacer una cruzada contra ellos y remedien el asunto, y cuando envíen los paquetes de periódicos a la intemperie, los protejan. ${ }^{45} \mathrm{H}$ abla, en fin, de

40. "Soi rées de M r. Levasseur", en El Tío..., op. cit., 9 de septiembre de i849, t. I, núm. 4, p. 55.

4I. "San Ángel", en El Tío..., op. cit., is de agosto de I849, t. I, núm. I, p. I4.

42. "Gas en el teatro", en El Tío..., op. cit., i6 de septiembre de i849, t. I, núm. 5, p. 74.

43. "Rótulo antisombreril", en El Tío..., op. cit., 26 de agosto de i849, t. I, núm. 2, p. 2 I.

44. "Revolución femenil”, en El Tío..., op. cit., is de agosto de I849, t. I, núm. I, p. I3.

45. "Correos", en El Tío..., op. cit., ir de noviembre de I849, t. I, núm. I3, p. i98. 
losas que se han despegado del suelo, de caminos deteriorados, etcétera.

Con anterioridad se expuso que, aunque Giménez no ilustró su periódico durante la primera época, sí publicó una obra satírico-burlesca por entregas, probablemente perdida, titulada Ensayos magnéticos de el tío N onilla, que regaló a los suscriptores de su periódico y que iba acompañada de litografías realizadas por él mismo46 (pudo haberlas ejecutado en la litografía de M urguía, uno de los sitios donde se recibían suscripciones a su periódico). El 2I de octubre de i849, vencidas dificultades que no especifica, repartió el primer pliego acompañado de dos láminas litográficas. ${ }^{47}$ La entrega de los textos se llevó a cabo, aunque no la de todas las láminas. Giménez planeaba que serían doce, y aunque inició la entrega de la segunda parte de la obra, titulada El magnetismo aplicado a la política, que también estaría ilustrada, ${ }^{4}$ sus planes se vieron truncados, primero porque debió dedicar su atención a los violentos sucesos que hicieron renunciar al ayuntamiento formado por conservadores y presidido por Lucas Alamán, y segundo, porque lo expulsaron del país.49

D os de los temas que mayor riqueza ofrecen en El Tío N onilla son la vida del teatro, de la cual algo se ha citado, y la política. Ambas constituían, al parecer, la pasión de Joaquín Giménez, y ello se manifiesta en su activa participación en ellas. El primer tema está equilibrado con el segundo en el tomo de i849, pero en el tomo de i85o la política adquiere mayor importancia, por ser éste un año de elecciones.

46. En principio G iménez señaló que la obra constaría de tres tomos "A nuestros suscriptores", en El Tío..., op. cit., 2i de octubre de i849, t. I, núm. io, p. I48; posteriormente dijo que constaría de dos partes: la primera tendría seis u ocho pliegos, en "A nuestros suscriptores", en El Tío..., op. cit., 28 de octubre de i849, t. I, núm. II, p. I65.

47. Al concluir la obra pensaba entregar portadas, índice y tabla para la colocación de las láminas. "A nuestros suscriptores", en El Tío..., op. cit., 2I de octubre de I849, t. I, núm. ıo, p. I48.

48. "A nuestros suscriptores", en El Tío..., op. cit., in de noviembre de I849, t. I, núm. I3, p. 208.

49. Los redactores que continuaron con la publicación señalaron que los Ensayos magnéticos se suspendían por el destierro de su autor, pero que la obra se reanudaría cuando éste enviara los originales desde M obila. "Ensayos magnéticos", en El Tío..., op. cit., 6 de enero de i85o, t. I, núm. 20, p. 3I4. Al reiniciar su segunda época, El Tío N onilla anunció que continuaría publicando entre otras obras los Ensayos magnéticos, pero no se sabe si en efecto lo hizo. "A mis antiguos sucritores. Prospecto de este segundo tomo, segunda época de El Tío N onilla", en El Tío..., op. cit., 29 de agosto de i85o, t. II, núm. I, p. II. 


\section{Giménez y la política mexicana}

En I849, año de la llegada de Giménez a M éxico, el país atravesaba un momento particularmente difícil. A la inestabilidad política, que desde la independencia había sido obstáculo insuperable para el desarrollo del país, pues mantenía inconcluso el proceso de construcción del Estado y tenía sumergida a la nación en el caos hacendario y en la corrupción administrativa, se sumaban la reciente y desastrosísima derrota en la guerra con Estados Unidos - a cuyas manos M éxico perdió más de la mitad de su territorio-, las guerras de castas en Yucatán y en Sierra Gorda, los continuos y terribles ataques de los indios nómadas en las poblaciones del norte del territorio, el enorme índice de criminalidad en las ciudades y en los caminos, y una epidemia de cólera que se prolongaría hasta septiembre de i850 y haría estragos en gran parte del país. Además, la agricultura y el comercio sufrían un gran decaimiento, todo ello agravado por el contrabando. D ebido a la falta de recursos, y a que los pocos que había se destinaban principalmente a vigilar y contener las continuas sublevaciones (la mayoría santanistas), el gobierno moderado de José Joaquín de Herrera no podía auxiliar a los estados que angustiosamente pedían la presencia del ejército. La cartera de Relaciones, pero sobre todo la de $\mathrm{H}$ acienda, fueron continuamente abandonadas por los funcionarios que topaban con la imposibilidad de realizar sus proyectos, rechazados a menudo por las cámaras legislativas. Por todo ello, la oposición acusó a H errera de incapacidad y también de debilidad, en particular frente a su ministro de Guerra, el general M ariano Arista, quien no sólo fue el "alma de su administración", so sino que aprovechó su posición para alcanzar la presidencia en el periodo siguiente. Esto explica la importancia que tuvo este personaje en la época y en las páginas de EI Tío N onilla. Un periódico de oposición, como fue éste en su primera época, abordó desde luego las distintas problemáticas del momento, capitalizándolas políticamente; preguntaba, por ejemplo, por qué el gobierno no había sometido a los "bárbaros" sublevados (de la Sierra y Yucatán), si en un rancho de D urango treinta "gringos" mataron a doscientos salvajes (es decir, los indios nómadas que saqueaban las poblaciones); ;r acusaba también al gobernador de la ciudad de M éxico, pues

50. M oisés González N avarro, Anatomía del poder en M éxic0, 1848-1853, M éxico, El Colegio de M éxico, 1977, p. 215.

5I. "Preguntas sueltas", en El Tío..., op. cit., 23 de septiembre de i849, t. I, núm. 6, p. 84. 
mientras los robos aumentaban, él hacía grandes proezas pasándola en el blando lecho sin velar por la tranquilidad de los gobernados. ${ }^{52}$

Aunque con algunas diferencias de apreciación en cuanto a cuáles fueron los grupos políticos que actuaron durante los años i848-1850, y sobre la manera de denominarlos, 53 en general las opiniones coinciden en que fueron tres los principales partidos políticos: los conservadores, los liberales puros y los liberales moderados; al lado estaban las llamadas facciones: la principal era la santanista, pero estaba también la almontista. Cada grupo intentaba imponer su proyecto de nación, o bien a su caudillo. Los conservadores pugnaban por preservar los elementos tradicionales del Estado colonial que les beneficiaban: un Estado fuerte y centralizado en alianza con la iglesia y el ejército, y el rechazo a la participación política de las clases bajas. Luchaban por establecer un sistema monárquico con apoyo de Europa, e intentaban neutralizar la injerencia norteamericana. Los liberales puros querían erradicar los vestigios de tradicionalismo: limitar el poder económico y político de la iglesia y reducir la injerencia política del ejército creando una milicia cívica; querían instalar el federalismo y hacer partícipes a las masas urbanas. Los liberales moderados coincidían con los anteriores en limitar el poder del ejército y la iglesia, pero no reclamaban reformas inmediatas; rechazaban la participación de las clases bajas y las llamaban con sustantivos denigrantes; la milicia cívica debía estar formada por ciudadanos propietarios; en i848 se inclinaron por la federación. 54

En cuanto a las facciones, por supuesto la santanista trabajaba en favor de Antonio López de Santa Anna, figura que ocupó un lugar primordial en la política mexicana a partir de la independencia, y cuyo prestigio había declinado con la reciente derrota con los Estados U nidos; sin embargo, sus partidarios, animados y financiados por él desde el exilio, primero en Kingston y luego en Turbaco, luchaban por su regreso para establecer una dictadura militar. La facción almontista, que luchaba para que Juan N epomuceno Almonte alcanzara la presidencia, según un observador contemporáneo carecía

52. "Robos", El Tío..., op. cit., 28 de octubre de i849, t. i, núm. II, p. I67.

53. Véanse, por ejemplo, las opiniones de un personaje prominente como $\mathrm{M}$ ariano 0 tero, 0 de un observador también contemporáneo y ahora desconocido cuyo nombre fue Vicente C azarín. G onzález N avarro, op. cit., pp. 222 y 237-238.

54. Pedro Santoni, M exican at Arms. Puro Federalists and the Politics of War, $1845-1848$, T exas, T exas Christian U niversity Press Fort W orth, 1996, pp. 2-3. 
de programa, y lo suplía con frases sueltas y ambiguas como libertad moderada, garantías e integridad territorial. .55

La traumática guerra con los Estados U nidos tuvo sus costos políticos, y los partidos y grupos trataban de recuperarse atacando a sus contrincantes. Además de Santa Anna, el partido de los puros sufría de descrédito porque sus aliados, con aquél, habían impulsado abiertamente en i846 la guerra con Estados U nidos y eran reprobadas sus políticas radicales y su falta de tacto; pero sobre todo, porque durante la ocupación norteamericana algunos de ellos habían colaborado con los invasores, por lo que se les acusó de querer anexar M éxico al país del norte. En cuanto a los moderados, cargaron con la responsabilidad histórica de firmar la paz, y no faltó quien se lo reprochara. $\mathrm{H}$ aciendo uso político del tema, en su etapa santanista El Tío N onilla habló continuamente de la amenaza de nuevas expediciones de los "bandidos norteamericanos"; decía que mientras los "bárbaros del norte amenazaban las costas mexicanas", el "patriota" gobierno no se perdía un solo concierto y no atendía los llamados que la prensa hacía en relación al peligro. ${ }^{56}$ En su segunda época, como se ve adelante, el periódico utilizó el tema para hacer escarnio de Santa Anna y al gunos de sus colaboradores.

En este periodo era mucho más fácil derrocar a un gobierno que mantenerse en el poder; con tal de alcanzarlo o mantenerlo se hacían alianzas, muchas de las cuales resultaban incongruentes si se toman en cuenta las posturas a veces radicalmente opuestas de quienes participaban en ellas. Vistas retrospectivamente, dichas alianzas crean una compleja serie de vínculos efímeros y pragmáticos entre los distintos grupos políticos ${ }^{7}$ que, determinados por sus propios intereses, eran disueltos en el momento que se consideraba conveniente. D urante el gobierno de Herrera se rumoró en diversos momentos sobre "fusiones"; en octubre de i849 El M onitor Republicano habló de alianzas entre conservadores y santanistas (alianza en la que participó El Tío N onilla al fin de su primera época); El M onitor Republicano recordó también la que se intentó entre conservadores y puros, pero dijo que, llegado el momento de la renovación del ayuntamiento, los conservadores se habían

55. Este observador desconocido fue Vicente Cazarín. González N avarro, op. cit., pp. $237-238$.

56. "Invasión" y “N uestro gobierno es más filarmónico que patriota”, en El Tío..., op. cit., 2 de septiembre de 1849 , t. I, núm. 4, p. 46.

57. En el libro de Santoni, op. cit., queda muy claro este continuo hacer y deshacer pactos por parte de los grupos políticos durante el periodo de i845 a i 847 . 
quedado con todo y sólo prometieron a sus aliados parte de las diputaciones del Congreso de la U nión..$^{8}$ Por su parte, Arista habló hacia enero de i850 de la colaboración de algunos liberales "alucinados" que incomprensiblemente cooperaban con el "establecimiento de una dictadura que preparase la venida de un monarca a nuestro suelo". 59 Para la oposición, el enemigo a vencer por medio de la opinión pública o de las armas era el gobierno moderado, que consumía buena parte de sus recursos en el sometimiento de las sublevaciones y en el financiamiento de una prensa que lo favoreciera. D urante i848 había tenido que reducir al orden al general $M$ ariano Paredes y Arrillaga, quien en Guanajuato, apoyado por el célebre padre Jarauta y algunos puros entre los que se encontraba $M$ anuel $D$ oblado (disgustado éste por haber sido destituido de la gubernatura del estado), había impulsado una sublevación monarquista pretextando una animadversión en contra de los tratados de paz. Respecto a las sublevaciones santanistas, sobre cuyo surgimiento abundaron los rumores, el gobierno enfrentó la de Leonardo M árquez, quien el io de febrero de i849 abandonó con sus tropas la lucha en Sierra G orda para pronunciarse en favor del general desterrado. I gualmente, en abril y marzo de i85o hubo sublevaciones que lo apoyaron, y en junio del mismo año Riva Palacio se enteró de que los santanistas intentaban infructuosamente hacer aliado suyo a Juan Álvarez, el caudillo del sur. Como sea, las alianzas también sirvieron para mantener el poder, pues para que Arista venciera en las elecciones de i85o se requirió hacer una alianza en el congreso entre moderados y puros. ${ }^{60}$

Una de las principales armas en la lucha política fue la prensa, y cada grupo, para difundir su postura, impulsó y financió sus periódicos. Es muy probable que EI Tío N onilla haya sido pagado en su primera época por Santa Anna, quien desde el extranjero sostenía entre otros periódicos La Palanca y El H uracán, y en general financiaba la campaña contra M ariano Arista. ${ }^{6}$ En la segunda época es probable que el periódico de Giménez fuese sostenido

58. G onzález N avarro, op. cit., p. 236.

59. Ibidem.

6o. Salvador Rueda Smithers, El diablo de Semana Santa. El discurso político y el orden social en la ciudad de M éxico en I850, M éxico, Instituto N acional de Antropología e H istoria, I99I (C olección Divulgación), p. 298. Sobre esta alianza, véase también $\mathrm{N}$ iceto de Zamacois, H is toria de M éico desde sus tiempos más remotos hasta nuestros días, Barcelona-M éxico, J. F. Parres, I880, vol. XIII, p. 417.

6I. J uan Suárez de $\mathrm{N}$ avarro, quien (como se ve adelante) fue durante esta época un ardiente colaborador de Santa Anna, después de su ruptura con Santa Anna en i853, reconoció que éste había financiado la campaña contra Arista. González N avarro, op. cit., p. 245. 
justamente por Arista, quien, como se señala más adelante, también financió distintas publicaciones para consolidar su fuerza política.

Durante su primera época El Tío N onilla atacó al periódico oficialista EI M onitor Republicano, y en su segunda época se hizo su aliado. Para entonces Giménez incluso publicó en este periódico escritos que eran réplicas 0 ataques a periódicos como La Palanca, El H uracán y El Lancero, creados por sus antiguos aliados. La mayor parte de estas publicaciones no se ha conservado, quizá por haber sido efímeras y de menor envergadura que El Siglo Diez y Nueve, El M onitor Republicano o El U niversal.

Como se mencionó, Giménez fue un hombre que estuvo envuelto en los vaivenes de la política en España, su país natal. N o se sabe si en Cuba desarrolló alguna actividad de este tipo, pero en M éxico su periodismo político fue efervescente y oscilatorio. Se dijo ya que en un plazo brevísimo de dos meses había salido de Cuba y se había anunciado como periodista en nuestro país, adoptando una prematura postura política. Aunque nunca lo dijo claramente, Giménez fue santanista durante el tiempo que dirigió la primera época de EI Tío N onilla. Esto lo indican las posteriores recriminaciones que le hicieron sus opositores respecto de haber apostatado de sus principios ${ }^{62} \mathrm{y}$ también un folleto que circuló en I850, en el que se acusaba de traidor a Santa Anna por haberse vendido a los norteamericanos durante la guerra de I847, y en el que se citaba un artículo del "memorable Tío Nonilla". El folleto decía que a dicho periódico se le había tenido por santanista, aunque nunca había abogado directamente por Santa Anna, "quizá porque así conviniese a sus miras [de Giménez], o porque se avergonzara de defender tal traidor". ${ }^{63}$ El propio Giménez lo confirma en una carta que remitió el 27 de julio de i85o a El Monitor Republicano, cuando ya había vuelto a M éxico y apoyaba al partido moderado. En ella se defiende de un ataque del periódico santanista La Palanca, y dice: "jamás defendí en mis publicaciones al general

62. Sucesivamente lo acusaron La Espada de Damodes, La Palanca y EI M ensajero (éste lo acusó también de haber colaborado con los conservadores). "La espada de D amocles", en EI Tío..., op. cit., sin fecha, t. II, suplemento del núm. 2, p. 4; "La palanca”, en El Tío..., op. cit., 28 de septiembre de I850, t. II, núm. 4, p. 53; y "O riginalidades del mensajero", en El Tío..., op. cit., 7 de noviembre de i85o, t. II, núm. Io, p. I55.

63. Anónimo, Antonio López de Santa Anna / Candidato para la próxima presidencia, M éxico, Imprenta de Vicente G. T orres, en el ex convento del Espíritu Santo, I85o. Este impreso se encuentra inserto entre las páginas de EI M onitor Republicano, en el ejemplar del Fondo Reservado de la $\mathrm{H}$ emeroteca $\mathrm{N}$ acional de $\mathrm{M}$ éxico. 
Santa Anna, si bien favorecí indirectamente a sus principales agentes, porque desconocia, como nuevo en el pais, la clase de gentes que son los dueños de dicho periódico [La Palanca], y a los que ahora conozco perfectamente". ${ }^{64}$ En otro remitido que envió también a El M onitor Republicano, en el que contestaba un ataque de los redactores del O riente, Giménez reconocía haberse equivocado en su anterior postura política, pero aclaraba que nunca había cobrado los servicios prestados al partido al que estuvo afiliado. ${ }^{65}$

Giménez señala implícitamente a los redactores de La Palanca como aquellos con quienes estuvo ligado. Es oportuno señalar que el principal redactor de dicho periódico, sostenido por Santa Anna, fue el activo Juan Suárez de $\mathrm{N}$ avarro, quien fungía como apoderado del general en el destierro, y que sería uno de los personajes más criticados y caricaturizados por Giménez en la segunda época de El Tío N onilla. Esta hipótesis se reafirma con las sucesivas declaraciones que había hecho El M onitor Republicano ${ }^{66}$ en el sentido de que el sucesor de El Tío N onilla (en su primera época) era El Huracán, periódico en el cual también escribió Suárez de $\mathrm{N}$ avarro. ${ }^{67}$ Este hombre no sólo criticó al gobierno, sino en particular al general Arista, quien en mayo de 1849 ordenó que se le formara causa por un artículo que publicó en La Palanca. Suárez de N avarro contraatacó intentando reanimar una causa en contra de Arista por las derrotas de Palo Alto y la Resaca. Finalmente, el santanista fue encarcelado por sus críticas al gobierno. ${ }^{68}$

Al contar con la información anterior, y habida cuenta de que los santanistas estaban en favor de una dictadura militar, se entienden mejor los velados comentarios de Giménez en la primera época de El Tío N onilla. En ellos se opone al monarquismo y al federalismo, el cual le parece que está a un paso de la anarquía y permite que hombres ignorantes, ambiciosos y sin patriotismo roben y asesinen impunemente. ${ }^{69} \mathrm{C}$ ritica que en $M$ éxico sólo se copie la "alharaca política gringa" y no sus medidas liberales respecto al co-

64. "Gacetilla de la capital”, en El M onitor..., op. cit., 27 de julio de I850, núm. I90I, p. 4.

65. Ibidem, io de junio de i850, núm. I854, p. 3.

66. Ibidem, io de mayo de ı850, núm. I823, p. 4, y 30 de mayo de ı850, núm. I843, p. 3.

67. Rafael Junguito, Contestación al alegato presentado por D. Juan Suárez de N avarro en la causa instruida al teniente coronel D. Rafael Junguito, por difamación, M éxico, Imprenta de Vicente $\mathrm{G}$ arcía Torres, a cargo de L. Vidaurri, I850, p. 6.

68. Supuestamente fue encerrado durante un año. González N avarro, op. cit., pp. 24I-242.

69. "D e la federacion á la anarquía, no hay sino un solo paso", en El Tío..., op. cit., iI de noviembre de I849, t. I, núm. I3, pp. 193-195. 
DOI: http://dx.doi.org/10.22201/iie.18703062e.2000.76.1898

200

HELIA EMMA BONILLA REYNA

mercio, la industria y el trabajo, por lo que en M éxico los federales y los monarquistas tienden al retroceso, y resultan inviables tanto una república como una monarquía. ${ }^{70}$ Constantemente muestra su posición antigubernamental y a los hombres en el poder, provenientes del partido moderado, los llama casta de pájaros y reconocidas nulidades, ${ }^{71}$ que llevan a la patria a la destrucción y a la barbarie; ${ }^{72}$ a menudo los llama también mandarines.73 Se refiere despectivamente al presidente José Joaquín de H errera, también moderado, al que llama buen hombre, que en nada se mete y a quien nadie le hace caso. ${ }^{74}$ En una época en que los levantamientos santanistas irían creciendo, Giménez ironiza sobre el miedo del gobierno a los pronunciamientos, y denuncia que está obsesionado por tener que enfrentarse a ejércitos revolucionarios, por lo que saca a ciudadanos pacíficos de su casa y los encarcela.75 Pregunta Jiménez al gobierno por qué, para poner fin a los robos que cometen los empleados gubernamentales en M azatlán, no envía a algunos de sus esbirros allá, en lugar de mandarlos a que anden por los cafés vigilando si alguien quiere elegir a Santa Anna como diputado. ${ }^{76}$ Critica también la inutilidad, negligencia e ineptitud de diputados y senadores, 77 y sugiere que el congreso se suprima y que el gran costo que éste significa al presupuesto nacional sea aplicado a la creación de un ejército y una marina eficientes, y también a escuelas de enseñanza gratuita. ${ }^{78}$ Excepcionalmente Giménez, haciendo ostentación de imparcialidad, señaló que aunque consideraba que la mayoría de los funcionarios del gobierno eran ineptos y antipatriotas, algunos como Arista, ministro de Guerra, tenían interés en que el país mejorara; reconocía su labor por tratar de promover la organización y reforma del ejército. ${ }^{79} \mathrm{EI}$ Tío N onilla aclaró que su apreciación no se debía al miedo 0 a

70. "Revista impolítica de la semana", en El Tío..., op. cit., 26 de agosto de ı849, t. I, núm. 2, pp. I7-I9.

7I. "Viva la ley", en El Tío..., op. cit., 9 de septiembre de I849, t. I, núm. 4, pp. 6I-62.

72. "A la juventud de M éxico", en ibidem, p. 59.

73. "M edidas inquisitoriales", en El T ío..., op. cit., 30 de septiembre de i849, t. I, núm. 7, p. io7.

74. "El Tío N onilla a su compadre Joaquín: Fraterna", en El Tío..., op. cit., i4 de octubre de I849, t. I, núm. 9, p. I32.

75. "M edidas inquisitoriales", en El Tío..., op. cit., zo de septiembre de i849, t. I, núm. 7, p. io7.

76. "Preguntas sueltas", en El Tío..., op. cit., 23 de septiembre de I849, t. I, núm. 6, pp. 84-86.

77. "Proezas de los diputados" y "H eroísmo de los senadores", en El Tío..., op. cit., 28 de octubre de I849, t. I, núm. II, p. I66.

78. "Diputados y soldados", en El Tío..., op. cit., 7 de octubre de ı849, t. I, núm. 8, p. II3.

79. “Ejército”, en El Tío..., op. cit., I6 de septiembre de ı849, t. I, núm. 5, p. 66. 
la esperanza de una gratificación, sino al deseo de ser justo. ${ }^{80}$ Sin embargo, como se verá adelante, quizá sí sondeaba la posibilidad de obtener algún beneficio.

A veces, algunas de las críticas que emitió resultan paradójicas, dado que podían aplicarse al propio periódico. Por ejemplo, la de que la libertad de imprenta, al permitir opiniones diferentes, promovía la discordia entre los mexicanos: ciertamente El Tío N onilla hizo esto con particular insidia. También es paradójica su afirmación, en tono de guasa, de que los diversos periódicos habían acordado utilizar un nombre en el que su postura política se explicitara, por ejemplo, puro, monarquista, moderado, santanista, camaleón, etcétera, para que se les pudiera identificar; ${ }^{81}$ no obstante, durante la primera época, mientras colaboró en El Tío N onilla, Giménez nunca aclaró la suya.

El 9 de diciembre se anunció en el periódico que Giménez había sido amenazado de destierro por el general Pedro Anaya, gobernador de la capital, porque le había disgustado el último suplemento en el que denunciaba el pronunciamiento ministerial provocado por los moderados, con el cual lograron hacer renunciar al ayuntamiento conservador. El motín al que se refería fue orquestado por Arista, ministro de Guerra, y seguidores suyos como el ministro de Relaciones, Lacunza, el propio general Anaya, el comandante general Benito Q uijano y otros. En la mañana del ${ }^{0}$ de diciembre se habían pegado carteles en que se criticaba a los conservadores y se pedía al congreso que anulara la ley por la cual el ayuntamiento tenía injerencia en la organización de las elecciones. A media noche, una multitud del pueblo apedré las casas de algunos de los miembros del ayuntamiento e intentó allanar la imprenta de El U niversal sin que el gobierno interviniera y contuviera el desorden. Al día siguiente, expresando su indignación en torno a lo ocurrido, los capitulares renunciaron. ${ }^{82}$ La prensa protestó por lo hechos, pero el que se distinguió por la censura que hizo de los hechos, según el historiador $\mathrm{N}$ iceto de Zamacois, fue El Tío N onilla..$^{83}$ En efecto, en una irónica nota titulada "Anécdota patriótica", el periódico acusó a Herrera de ocuparse de nimiedades mientras la nación tenía problemas. Así, al tiempo que el pueblo "soberano" gritaba por las calles y apedreaba vidrieras, él Ilevaba una

80. "Diputados y soldados", en El Tío..., op. cit., 23 de septiembre de I849, t. I, núm. 6, p. 8I. 8I. "Periódicos nacionales", en El Tío..., op. cit., 2I de octubre de I849, t. I, núm. Iо, p. I49. 82. G onzález N avarro, op. cit., pp. 224-231, y Zamacois, op. cit., pp. 310-339.

83. Zamacois, op. cit., p. 324. 
"patriótica" maceta para ornamentar la casa que construía en Tacubaya. El Tío N onilla llamaba al presidente "cándido", y le decía que otro hombre se elevaría por encima de él, aludiendo a Arista. En el mismo número se advertía que los gobernantes preparaban otro pronunciamiento. ${ }^{84}$

A partir del i6 de diciembre se hizo evidente la alianza, o la búsqueda de ella, entre el santanista El Tío N onilla y algunos conservadores, pero no se sabe si Giménez llegó a participar en ella porque para entonces había sido arrestado. En M éxico a través de los siglos se habla del "descarado e insolente" El Tío N onilla como periódico conservador, y se refiere irónicamente a "Joaquín Jiménez [como] gran H omero de los munícipes conservadores á propósito de una exposición de plantas, verduras y muñecos de trapo que aquellos improvisaron en el jacalon levantado en la plaza de armas". ${ }^{85}$ Lo cierto es que a los pocos días de la renuncia del ayuntamiento conservador encabezado por Lucas Alamán, Giménez fue expulsado de M éxico. En la portada del número del I6 de diciembre de i849 se anunció la "Infame conducta del gobierno con D on Joaquin Jiménez / Director en gefe de este periódico". En el texto se dice que el gobierno aprovechó uno de los escándalos del teatro, ocurrido el día 5 de diciembre, para imputárselo a Giménez, y aunque testigos honorables desmintieron esto, el periodista fue detenido dos o tres días después, quedando preso otros tantos. El día io el español envió una carta al gobierno, señalando que ignoraba la causa de su encierro y solicitando que se le liberara o se le expidiera pasaporte. El i2 de diciembre fue escoltado por dos oficiales sin que se le permitiera recoger sus cosas. ${ }^{86}$ Él mismo recordaría posteriormente que tuvieron la amabilidad de enviarlo a guisa de fardo en una diligencia y luego en un pequeño camarote del inmenso vapor Tymes [sंc] a Estados U nidos. ${ }^{87}$

El Tío Nonilla continuó siendo publicado por el resto de los redactores por lo menos hasta el i7 de febrero de ı850, y a ellos se debe que el periódico

84. “Anécdota patriótica” y “El Sr. Anaya”, en El Tío..., op. cit., 9 de diciembre de i849, t. I, núm. I7, pp. 26i y 266.

85. Enrique O lavarría y Ferrari et al., M éxico a través de los siglos, M éxico, Cumbre, I977, t. Iv. M éxico independiente, p. 73i. En efecto, Giménez había dedicado uno de sus suplementos a la reseña de dicha exposición.

86. "I nfame conducta del gobierno con D on Joaquin Jiménez / D irector en gefe de este periódico", en El Tío..., op. cit., I6 de diciembre de i849, t. I, núm. I8, pp. 273-284.

87. “¡A paseo!!-U na Revolución!”, en El Tío..., op. cit., 28 de noviembre de i85o, t. iı, núm. I3, p. 202. 
declarara de manera abierta y franca su postura santanista y conservadora. En el mismo número en el que se denunciaba la amenaza a Giménez, se decía ya que los monarquistas no querían un rey sino un buen gobierno, y se proclamaba a Santa Anna como el más apto, digno y capaz para dirigir a M éxico, achacándole sus errores anteriores a quienes lo rodearon y mal aconsejaron. D enunciaba igualmente que junto con EI Monitor Republicano se había repartido un folleto titulado ¡M uera $\mathrm{D}$. Lucas Alamán! ${ }^{88}$ En su número siguiente, del 16 de diciembre de i849, se afirmaba que si el pueblo mexicano no reaccionaba pronto, tendría en el trono a un puro de los que ocupaban el poder en vez de alguien elegido por los monarquistas, quienes tenían juicio y talento. ${ }^{89}$

En el primer número de la segunda época de El Tío N onilla, que apareció el 29 de agosto de i85o, último año del gobierno de Herrera, Giménez en parte explicaría lo ocurrido. Primero, menciona que hubo desacuerdo entre los sucesivos redactores durante la época anterior, y luego afirma en tono amargo que fueron sus propios amigos quienes, al ver que sus enemigos se enfurecían con él, lo denunciaron como perjudicial al orden público.9 $9^{\circ}$ Entonces - continúa - sólo recibió la ayuda desinteresada del excelentísimo señor conde de la Cortina (quien - según él - era ajeno a la política, pero que en realidad había estado y volvería a estar muy cerca de Santa Anna) ${ }^{91}$ y

88. “¡M uera D. Lucas Alamán!!”, en El Tío..., op. cit., 9 de diciembre de ı849, t. I, núm. I7, p. 268.

89. "Infame conducta del gobierno con D on J oaquin Jiménez / D irector en gefe de este periódico", en El Tío..., op. cit., I6 de diciembre de I849, t. I, núm. I8, p. 284.

90. "Reflecsiones y profesion de fe que hace El Tío N onilla en su segunda época" y "A mis antiguos sucritores. Prospecto de este segundo tomo, segunda época de EI Tío N onilla", en EI Tío..., op. cit., 29 de agosto de i850, t. II, núm. I, pp. 5, 9 y ı.

9I. Expulsado por la ley del Caso, el conde de la Cortina volvió a M éxico para colaborar con Santa Anna en I834. Posteriormente, en I854, fue condecorado por el caudillo con la O rden de Guadalupe; el mismo conde se encargó de preparar la fastuosa ceremonia de reinstalación de la O rden, y preparó el baile que en esa fecha ofreció Santa Anna, Su Alteza Serenísma, en Palacio N acional. Además, según Romero de Terreros, el conde hizo cuantiosos préstamos al último gobierno del general, y debido a que nunca los recuperó, arruinó su fortuna. V éase M anuel Romero de Terreros (prólogo y selección), Poliantea: conde de la Cortina, M é xico, U niversidad N acional Autónoma de M éxico, 1944 (Biblioteca del Estudiante U niversitario), pp. XI-XII y xvi. Por su parte Pedro Santoni señala que el conde perteneció a la Junta de N otables que creó las Bases 0 rgánicas de i843, constitución que amplió los poderes del ejecutivo, encabezado por Santa Anna, y bajo la cual el general estableció su primera dictadura. En agosto de 1846 Santa Anna regresó gracias a una frágil y conflictiva alianza entre puros, 
del coronel don Ángel Cabrera. Este último fue abierto partidario de Santa Anna, y un año más tarde publicó el periódico El Lancero para defenderlo de los ataques de EI Tío N onilla. $9^{22}$

La expulsión de Giménez fue celebrada tanto por El Siglo Diez y Nueve93 como por El M onitor Republicano. Este último se enfrascó en una discusión con el periódico Le Trait d'U nion, que criticó que los extranjeros estuvieran indefensos en M éxico, y con El Globo, que denunció que la expulsión se hubiera hecho sin fórmulas legales. Al primero le respondió que el propio ministro español no había reconocido a Giménez como súbdito de España, y que por lo tanto no tenía nacionalidad legalizada, y continuaba: "Ios que no tienen nacionalidad, los que han sido desnaturalizados en su primitivo pais, y no han sabido hacerse buenos hijos de otro" son por sí mismos parias, y M éxico, como otros países, tiene derecho a expulsar a quien es motivo fuerte del desorden civil. ${ }^{44} \mathrm{Al}$ segundo, le repetía lo anterior y añadía que Giménez no estaba sujeto a ningún deber ni tenía derecho a reclamar ninguna garantía. H abía abusado de la libertad de imprenta, derecho del cual no podía hacer uso puesto que no era miembro político de la sociedad. 95

Las razones que Giménez arguyó para abrazar la causa del partido moderado fueron únicamente sus desavenencias personales; en ningún momento mencionó que su ruptura con los santanistas se hubiese debido a divergencias políticas. Por otra parte, si bien ser santanista tuvo distintas connotaciones a lo largo de los distintos periodos que siguieron a la independencia (por los vaivenes políticos del propio Santa Anna), esto no ocurrió durante el breve tiempo que se publicó El Tío N onilla, en el que Herrera se mantuvo como presidente. En este lapso los santanistas lucharon contra el partido moderado y en particular contra Arista (su candidato a la presidencia para I85I), estableciendo al ianzas coyunturales e intentando recuperar espacios. A pesar de las afirmaciones de Giménez, es necesario considerar la convenien-

santanistas y moderados; entonces el conde fungió como gobernador del D istrito Federal, cargo desde el cual trató de debilitar al partido radical, el cual ya había pedido a Santa Anna que lo depusiera, pero el general no aceptó, arguyendo que confiaba en el conde. Santoni, op. cit., pp. 20-2I y I49-155.

92. "El Lancero", en El Tío..., op. cit., 29 de agosto de i850, t. II, núm. I, p. i6.

93. "El tío N onilla", en El Siglo Diez y N ueve, M éxico, i4 de diciembre de i849, t. iı, núm. 348, p. 718.

94. "Gacetilla de la capital”, en El M onitor..., op. cit., I3 de diciembre de I849, núm. I675, p. 4. 95. Ibidem, is de diciembre de i849, núm. I677, p. 4. 
cia económica como una de las posibles razones de su viraje. El periódico El O riente, al volver Giménez a M éxico, afirmó que éste se había involucrado con un partido que lo comprometió sin cumplirle las promesas que le hizo, insinuando que había cobrado por sus servicios. ${ }^{96}$ Posteriormente, El H uracán también acusó a El Tío N onilla de la segunda época de ser financiado por Arista. ${ }^{97}$ Asimismo, El M ensajero le recriminó ser sostenido por el ministro de Guerra para calumniar y ridiculizar a sus enemigos políticos y personales. Según este periódico, El Tío N onilla recibía \$I ooo.oo mensuales, puesto que su impresión era costosa y la publicación contaba con pocas suscripciones. $9^{8}$ Por otra parte, cuando los redactores de El Tío N onilla denunciaron la expulsión de Giménez a fines de 1849 señalaron que desde el principio uno de los ministros (quizá se refieren a Arista, a quien ya en su primera época El Tío Nonilla llegó a elogiar, como se señaló antes), por medio de un diputado, al ver que el español atacaba al gobierno, lo quiso conocer fingiéndole amistad, luego trató de sobornarlo y le ofreció un puesto en alguna colonia del norte para alejarle. ${ }^{99}$ Respecto al uso de la prensa por parte del general Arista, EI U niversal llegó a afirmar que financiaba alrededor de 45 periódicos, al gunos de ellos tan grandes como el Clamor Público, y que durante el periodo previo a las elecciones invertiría en ellos aproximadamente \$36 ooo.oo. En su momento, Giménez refutó las acusaciones; en particular, Ilama la atención la respuesta que dio a El U niversal, pues en ella señalaba que la supuesta suma era exagerada, y que era más fácil alquilar articulistas independientes y barateros. ${ }^{100}$ Tras todos estos comentarios, se trasluce la existencia de cierta prensa financiada con fines políticos, y la de escritores puestos al servicio del mejor postor.

No se sabe en qué momento Giménez dejó el santanismo para apoyar a quienes tanto había criticado y por quienes había sido expulsado. D urante su estancia en N ueva O rleáns, Giménez continuó escribiendo, y envió una amenazante carta que apareció en El Tío Nonilla el 3 de febrero de i850, todavía en su primera época, en la que decía que publicaría una obra titulada

96. "Revelaciones”, en EI M onitor..., op. cit., so de junio de i850, núm. I854, p. 3.

97. El artículo de El H uracán titulado "Presidencia de la República" es citado en "Remitidos", en El M onitor..., op. cit., 25 de julio de I850, núm. I899, p. 2.

98. "Al público", en El Tío..., op. cit., 30 de octubre de I85o, t. II, núm. 9, p. I44.

99. "I nfame conducta del gobierno con D on Joaquín Jiménez / D irector en gefe de este periódico", en El Tío..., op. cit., I6 de diciembre de I849, t. I, núm. I8, p. 273.

ıoo. "Revelaciones", en El M onitor..., op. cit., io de junio de I850, núm. 1854, p. 3. 
DOI: http://dx.doi.org/10.22201/iie.18703062e.2000.76.1898

206

HELIA EMMA BONILLA REYNA

Porvenir de la República M exicana, bajo la dominación del actual gobierno, en la que atacaría a los moderados (especialmente a Arista, ministro de Guerra, y a Lacunza, ministro de Relaciones), y daría a conocer los planes de anexión de M éxico a Estados Unidos por parte del gobierno. No hay indicios de cuánto la adelantó. En cambio, sí concluyó otra en la que recuperaba, de nuevo muy a su manera, su antigua inquietud de viajero. Comprendía una serie de cartas que entonces envió al conde de la Cortina. Se conocen gracias a que a su regreso a M éxico las publicó, aunque quizá incompletas, en las páginas de su antes acérrimo enemigo EI M onitor Republicano entre el i6 de julio y el 23 de agosto de i85o. Esta obra llevó el título de Cartas de D. Joaquín Jiménez (El Tío N onilla) sobre los Estados U nidos de America dirigi das desde $\mathrm{N}$ ew Orleans al Exmo. Sr. Conde de la Cortina y de Castro. ${ }^{\text {Ior }}$ En ella describiría las raras, estrambóticas, poco ilustradas e inhumanas costumbres de los norteamericanos, su comercio, agricultura, industria, política, su trato a los extranjeros, etcétera. Era una obra denostativa que pretendía dar a conocer a mexicanos, españoles y quienes quisieran, la verdad sobre dicho país (tan admirado entonces por los liberales). Llama a N ueva O rleáns el "país de las monas", y dice que en Estados Unidos reina eternamente la enfermedad "mono-imbécil-mimical". Aunque no sabemos si planeó integrarla a su libro de viajes, es probable que sí haya pensado en ilustrarla, porque en la segunda época de El Tío N onilla se publicó el 28 de noviembre de i85o una litografía copiada "de un diseño hecho en el terreno" por Giménez sobre las inundaciones del $\mathrm{M}$ ississipi ${ }^{102}$ (aunque lo mismo podría haberla hecho de memoria, porque el dibujo es primario).

Ior. Ibidem. "Cartas de D. Joaquín Jiménez (EI Tío N onilla) sobre los Estados U nidos de América dirigidas desde $\mathrm{N}$ ew $\mathrm{O}$ rleans al Exmo. Sr. Conde de la Cortina y de Castro", en EI M onitor..., op. cit., i6 de julio de i85o, núm. ı89o, pp. 3-4.

IO2. Probablemente por un error del cajista, en el texto se señala que el diseño de la lámina fue hecho por el Sr. Jimeno, en vez de Jiménez (variación ortográfica con la que ocasionalmente se hace referencia al director de EI Tío $\mathrm{N}$ onilla en las propias páginas del periódico). "Inundaciones de M ississipi", en El Tío..., op. cit., 28 de noviembre de I850, t. II, núm. I3, p. 2or. $\mathrm{H}$ ay que señalar, sin embargo, que el estilo primario del dibujo es muy similar al de las láminas que hizo para el manuscrito "La H abana por dentro". Por otra parte, cabe apuntar que Giménez continuó alimentando el interés viajero y publicó una pequeña obra que se tituló U na emigración en África, con noticias interesantes y curiosas, la cual llevaba láminas fuera del texto con vistas de los lugares y las escenas más interesantes. "U na emigración en África", en El Tío..., op. cit., I2 de diciembre de i850, t. II, núm. I5, p. 230. Esta obra volvería a ser editada por el escritor a partir de enero de i85i (junto con un nuevo periódico), y nuevamente 
La vuelta de Giménez fue comentada con distintas expectativas por la prensa capitalina. El 5 de mayo hablaban ya de su llegada El Oriente y El H uracán, este último encomiásticamente. ${ }^{103} \mathrm{El} 20$ de mayo de $1850 \mathrm{El} \mathrm{M}$ onitor Republicano la anunció en tono molesto. ${ }^{104} \mathrm{~N}$ o obstante, días después, el Io de junio, este periódico daba cabida en sus páginas a un largo remitido del español escrito casi un mes atrás, el 7 de mayo. En él, G iménez se dirigía a El H uracán, periódico santanista que había afirmado que el español sostendría su anterior postura, para aclararle su rompimiento con los partidarios de Santa Anna, a quienes calificaba como gavilla de pillos. Contestaba también a El O riente que el gobierno estaba tranquilo porque él cumpliría su palabra de no mezclarse en los asuntos políticos del país y negaba que hubiera vuelto a M éxico gracias a la intervención de personas notables por su posición social. Él mismo, confiando sólo en la caballerosidad, había acudido al gobierno, y obtenido permiso de permanecer en el país. Subrayaba que para él, su palabra de honor era muy valiosa. ${ }^{105}$

Independientemente de si intercedió o no por él, el conde de la Cortina fue un hombre de prominente posición social del cual estuvo cerca Giménez. El hecho de que lo visitara en la cárcel y de que el español le escribiera continuamente desde Estados U nidos lo confirma. En su primera carta Giménez lo trataba respetuosamente como vuestra excelencia, y le agradecía las pruebas de cariño fraternal y la ayuda que le había brindado en circunstancias desgraciadas; a la vez le manifestaba su estimación y cariño. Por otra parte, no resulta extraña una relación entre ambos, si se tiene en cuenta que el conde siempre estuvo cerca de España y de las letras, y que él mismo había publicado algunos años antes un periódico. Además, tampoco careció de sentido del humor, ${ }^{\text {Io6 }}$ expresado a veces con tintes muy ácidos, lo cual le permitiría apreciar la labor de Giménez (el título mismo de El Zurriago Literario, el periódico que publicó el conde, anunciaba su talante fustigador e inclemente).

contó con ilustraciones, las cuales, según se afirmó, serían medianamente litografiadas por el propio autor.

I03. "Revelaciones", en EI M onitor..., op. cit., io de junio de i850, núm. I854, p. 3.

I04. "El Sr. Jiménez", en El M onitor..., op. cit., 20 de mayo de I850, núm. I833, p. 4.

Io5. "Revelaciones" y “D on Joaquín Jiménez", en El M onitor..., op. cit., 7 de mayo de I850, núm. 1854, p. 3.

Io6. Romero de Terreros, op. cit., afirma en tono anecdótico que fue su sentido del humor el que le hizo regalar a la reina I sabel II una falsa espada que supuestamente había pertenecido 
El español se instaló en la villa de Tacubaya (donde, por cierto, también residía el conde de la Cortina); según él, viviría ahí en retiro, sin emprender trabajos penosos. Sin embargo, es posible percatarse de que estaba al tanto de lo que publicaba la prensa, por los constantes remitidos que hizo entonces a El M onitor Republicano. En ellos se defendía de las críticas personales que le hacían algunos periódicos y también se burlaba de ellos. Su carácter inquieto no le permitió cumplir su "importantísima" palabra de honor. ${ }^{107}$ Primero faltó a ella veladamente, pues a petición de algunos lectores de EI M onitor Republicano $0^{108}$ prometió escribir una defensa a la obra M isterios de la Inquisición, que se publicaba en dicho diario y en la cual se denunciaban los hechos infames del santo tribunal. En el fondo de este asunto había una pugna de partidos, pues la publicación de la obra mencionada suscitó una larga disputa entre el moderado El M onitor Republicano y el conservador EI U niversal, y Giménez salía en apoyo del primero. Posteriormente El Tío N onilla faltó a su palabra más abiertamente, al publicar, aunque sin firma, un artículo político titulado Los enemigos del órden y del país son tres (Santa Anna-padre, Almontehijo, Trono-espíritu santo) el 22 de julio en El M onitor Republicano. Volvieron las agitaciones para Giménez, a quien se encarceló después de que el artículo fue denunciado y declarado difamatorio. ${ }^{109}$ Continuó también la polémica entre los periódicos que opinaban sobre el hecho. Ante las acusaciones de

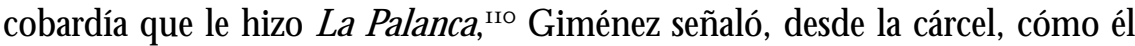
mismo, abandonando el "sagrado recinto" en que se encontraba, había venido de Tacubaya a la capital para buscar al juez encargado de su caso. U no de los redactores de EI M onitor Republicano también publicó un artículo para defenderlo. ${ }^{\text {III }}$

a Bernal D íaz del Castillo, y que durante muchos años sería exhibida en la Real Armería de $M$ adrid; narra también que en alguna ocasión cometió la travesura artística de falsificar unas pinturas (pp. XI-XII).

I07. "D on Joaquín Jiménez / El Tío N onilla”, en El M onitor..., op. cit., M éxico, ro de junio de I850, núm. I902, p. 3.

I08. "Remitido", en El M onitor..., op. cit., 27 de junio de I850, núm. I854, p. 3. Más que de un remitido de los lectores, quizá se trataba de un "autorremitido", puesto que a estas alturas Giménez y los redactores de EI M onitor Republicano ya habían hecho las paces.

Io9. "Fraternidad de los protestantes", en El M onitor..., op. cit., M éxico, 28 de julio de I850, núm. I902, p. 3.

IIo. "Remitido", en la G acetilla del M onitor, M éxico, I0 de agosto de 1850, t. I, núm. 3, p. 2.

iII. "Fraternidad de los protestantes", en El M onitor..., op. cit., 28 de julio de i850, núm. I902, p. 3. 
Giménez supuestamente continuaba preso cuando reinició la publicación de El Tío Nonilla, pues en el segundo número de éste, del 29 de agosto, se decía que estaba detenido por un artículo que había publicado en El M onitor Republicano. Por lo visto, el encarcelamiento no era ningún obstáculo para que sus escritos vieran la luz. En el primer número de El Tío N onilla habla de la traición de sus antiguos "amigos" y correligionarios, quienes eran líderes del partido al que pertenecían. Afirma que se trata de cuatro pillos que obraron cobardemente y cuya conducta reclama venganza, pues además de haber ocasionado su encarcelamiento y destierro, lo delataron cuando volvió furtivamente al país; por el contrario, los hombres a quienes había atacado habían sido generosos, olvidando el pasado, y permitiéndole atacarlos nuevamente. ${ }^{I 12}$ Fuese o no ésta la razón fundamental por la que el apasionado español cambió de bando político, lo cierto es que los santanistas serían ahora su principal blanco, aunque no el único. Giménez continúa afirmando que en la segunda época su periódico no tendrá ya amigos, y que criticará a cualquiera que no ande derecho, sea monarquista, santanista, moderado,

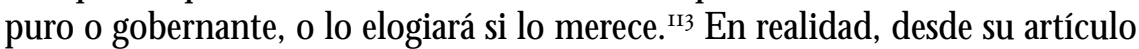
para El M onitor Republicano, por el cual fue encarcelado, era ya implícito su apoyo a la candidatura del general $\mathrm{M}$ ariano Arista para la presidencia.

El hecho de estar ahora en favor del régimen, hizo que Giménez adoptara un papel opuesto al que tuvo mientras fue redactor del periódico durante la primera época. Antes había denunciado el miedo del gobierno a los pronunciamientos, y en la segunda época, en distintos momentos, difundiría la amenaza de una revolución. ${ }^{I 4}$ En el primer tomo del periódico abogó para que se otorgase una pensión a los descendientes de Iturbide, "el padre que nos dio la Patria", "Ir y ahora atacaba a El U niversal, por llamar bandido a $\mathrm{H}$ idalgo, héroe de nuestra nacionalidad, capitalizando las fuertes críticas que desató durante i849 un artículo del periódico conservador en el que se denostaba la figura del cura y del movimiento que había encabezado. ${ }^{\text {II }}$

II2. "A mis antiguos suscritores. Prospecto de este segundo tomo, segunda época de EI T ío N onilla", en El Tío..., op. cit., 29 de agosto de i850, t. II, núm. i, p. ı.

II3. Ibidem.

II4. "A última hora" y "Amagos de una revolución", en El Tío..., op. cit., 5 de diciembre de I850, t. II, núm. I4, p. 221; y I2 de diciembre de I850, t. II, núm. I5, p. 224. Véase también la caricatura publicada en el número 8 , el 24 de octubre de i 850 .

iı5. "I turbide", en El Tío..., op. cit., 23 de septiembre de i849, t. i, núm. 6, p. 89.

ir6. "D e como El tío $\mathrm{N}$ onilla dice lo que le parece y con fundamento piensa, respecto al 
H asta el fin de la publicación, Giménez abogaría por el ministro de Guerra, defendiéndolo de los virulentos ataques que recibía de la prensa independiente. Señalaba que ésta propiciaba el desprecio a los primeros magistrados, y que de ahí nacían las revoluciones. El Tío la llamaba la "carcoma de nuestra prosperidad", de lo cual era prueba que narradores de hechizos y brujerías como lo eran los de El Universal, que vivían en contra de lo que oliese a libertad, hubiesen injuriado a un hombre llamado a mantener la paz del país y a llevarlo adelante. ${ }^{117}$ Es necesario señalar que, en la lucha por la presidencia de la república, los conservadores intentaron desprestigiar a Arista a través del periódico El U niversal, secundados por el santanista El Huracán, para evitar que fuera el egido candidato, y para ello intentaron responsabilizarlo calumniosamente del dramático crimen del diputado Juan de $D$ ios $C$ añedo, del que finalmente el general salió limpio. ${ }^{I 18}$ Eran éstas las principales injurias a que Giménez se refería, y tanto El Tío Nonilla ${ }^{\mathrm{II}}$ como El Siglo Diez y Nueve y El M onitor Republicano afirmaron la inocencia de Arista.

En esta época, la prensa era el medio de expresión más influyente; ella creaba el ambiente político conforme al cual se actuaba y opinaba. En particular, durante este momento la mesura no existió. Se hablaba sobre todo de política, y la mayor parte de los periódicos se destinaba a editoriales cargados de sarcasmos, apoyando a los correligionarios o renegando e incluso denigrando a los opositores.

largo y edificante sermon que á guisa de artículo de fondo, inserta el reverendo U niversal en su número del sábado último bajo el rubro de: $\mathrm{A}$ todos los mexicanos amantes de su patria", en El Tío..., op. cit., ı́ de diciembre de 1850 , t. II, núm. I6, p. 242. Es conocido el trasfondo ideológico de la agria polémica entre conservadores y liberales acerca de la valoración histórica de las figuras de $\mathrm{H}$ idalgo e Iturbide en torno al movimiento de independencia. Charles $\mathrm{A}$. $\mathrm{H}$ ale, El liberalismo mexicano en la época de $\mathrm{M}$ ora, ra. ed., M éxico, Siglo $X X I$, I994, p. 20.

II7. "¿Q ué es patriotismo? ¿Q uiénes son patriotas?", en El Tío..., op. cit., 29 de agosto de I850, t. II, núm. 2, pp. I8-ı9.

II8. Una narración detallada de este crimen y de su contexto político se encuentra en Rueda Smithers, op. cit.

in9. "Los calumniadores del Sr. Arista”, en El Tío..., op. cit., 2i de noviembre de i850, t. II, núm. I2, p. I79. 


\section{La segunda época de EI T ío N onilla y susilustraciones}

Al reaparecer, El Tío N onilla asumió un tono distinto al que tuvo al anunciar su primera época, sin por ello renunciar a su polemismo. Ahora alabaría lo bueno y vituperaría lo malo dentro del decoro, con mesura "de lenguaje para un público ilustrado y no en ese dialecto de verduleras, cuya lectura se hace imposible a las personas de delicadeza y educación". Sin embargo - decíasi por desgracia se le arrastraba a ese terreno, abriría una sección titulada "sección asquerosa", suplicándoles a los lectores de buena fe que la pasaran por alto. ${ }^{120}$ Tres meses después la publicación reconoció, no obstante, su extremismo verbal, admitiendo haber llenado sus columnas con denuestos, "vergonzosos si se quiere", contra personas y corporaciones, pero justificándose al señalar que lo había hecho orillado por sus cal umnias y crímenes. ${ }^{\mathrm{I2I}}$

D esde el principio da a conocer el nombre del otro redactor, el español José C asanova, su inseparable amigo y compañero de armas durante la última guerra en España y de redacción en sus publicaciones. ${ }^{122}$ Casanova también había residido en Cuba, pues en $M$ atanzas había colaborado en el periódico La Aurora. ${ }^{223}$

El Tío N onilla anunció que saldría ilustrado con estampas. Durante los tres primeros números, las caricaturas que se publican son exclusivamente grabados en madera, y por ello fue posible intercalarlos en el texto. En el número uno se aclara que la suscripción costará, como antes, un peso mensual, a pesar de los gastos que ocasionan los grabados. En una interesante nota se añade: "al gunos de los gravados de este número han servido en otras obras, porque contándose con muy pocos gravadores en la capital, no tenemos aun el depósito indispensable para que todos sean originales, como lo serán en muy breve". ${ }^{124}$

I20. "Reflecsiones y profesión de fe que hace el Tío N onilla en su segunda época", en El Tío..., op. cit., 29 de agosto de i85o, t. II, núm. I, p. 5.

I2I. "Exigencias del país. Deberes que deben llenar sus primeros magistrados", en El Tío..., op. cit., 28 de noviembre de i850, t. II, núm. I3, pp. 193-ı194.

I22. I bidem, p. 2. O casionalmente aparecieron colaboraciones de Casanova en EI M onitor Republicano: el 6 de septiembre publicó un poema escrito en Cádiz, y el 26 de octubre otro titulado justamente Cádiz, por lo que es muy probable que, como G iménez, fuese natural de esa región.

I23. "A nuestros amigos y modernos suscritores", en El Tío..., op. cit., 29 de agosto de i850, t. II, núm. I, p. 2.

I24. El Tío..., op. cit., 29 de agosto de i85o, t. iı, núm. i, p. iI. 
Joyce Bailey aclara cuál es el origen de una de las planchas que Giménez reimprime en El Tío Nonilla. Se refiere a la que ilustra el poema políticosatírico Reflexiones de un puro!! I25 del 30 de octubre de i850, la cual se había publicado dos años antes en El Calavera, y que representaba al pancista Gordiano $\mathrm{M}$ antecón. ${ }^{\mathrm{I2}}$ Por otra parte, varias de las caricaturas xilográficas provenían de al gunos calendarios editados por Vicente García Torres, editor de El M onitor Republicano: del Primer calendario de Vicente García Torres para 1849 y del Segundo calendario de Vicente García Torres para 1850. A su vez, algunas de estas imágenes habían sido copiadas de la publicación española La risa, enciclopedia de extravagancias, de 1843 y $1844 .{ }^{\mathrm{I} 27}$

Quizá porque en realidad no se consideraba dibujante, en principio Giménez prefirió adquirir imágenes ya hechas y no realizarlas él mismo. Por ello, al hacer la lectura, a menudo es notorio cómo el texto se va construyendo de tal manera que pueda servirse de esas imágenes preexistentes. Por ejemplo, en el prospecto del segundo tomo, que aparece en el primer número del periódico, se publicaron varias de personajes presuntamente representativos de las diversas posturas políticas. Al disponer de un grabado en que figuraba un hombre a caballo, Giménez acomoda su historia diciendo que se trata de un "trotón monarquista". ${ }^{\mathrm{r} 28}$

Esto también es notorio en sus historias secuenciadas, que casi son historietas, pues los mismos personajes se representan sucesivamente de maneras diversas, es decir, no conservan una identidad realmente fija (aunque conceptualmente sí lo hacen), y en ocasiones la imagen de plano no se corresponde con el texto. Además, la narración toma giros intempestivos que la hacen perder el ritmo. Un buen ejemplo son las imágenes que pertenecen a la serie Chanzas de Cupido. Publicada sucesivamente a partir del io de octubre de 1850 , en ella se critican las costumbres y se ataca al clero. Cito

I25. El Tío..., op. cit., 30 de octubre de i850, t. II, núm. 9, p. I45.

I26. Bailey, op. cit., p. 9i. C abe señalar que una ventaja de la xilografía sobre la litografía es la posibilidad de ser reutilizada, y en estos años, en M éxico, las imágenes pasaron a menudo de una publicación a otra. El grabado que cita Bailey, después de aparecer en EI Tío N onilla volvió a ser utilizado años después en el Calendario de José M aría Aguilar para 1860.

I27. Comparar la xilografía que apareció el i2 de septiembre de i85o en la página 44, número 3 del t. ir de EI Tío N onilla con la que aparece en la página I7o de La risa, 3 de marzo de I844, t. II, núm. I69.

I28. "A mis antiguos suscritores. Prospecto de este segundo tomo, segunda época de El Tío N onilla", en El Tío..., op. cit., 29 de agosto de i850, t. II, núm. I, p. ıo. 
Figura 2. Imágenes con las que concluye la serie Chanzas de Cupido, en El Tío N onilla, 30 de octubre de I850, t. II, núm. 9, p. I44, grabados en madera anónimos, probablemente tomados por Joaquín Giménez de otras publicaciones, I0.3 x I0.5 $\mathrm{cm}$, Fondo Reservado de la $\mathrm{H}$ emeroteca $N$ acional de M éxico. Foto: HEBR.

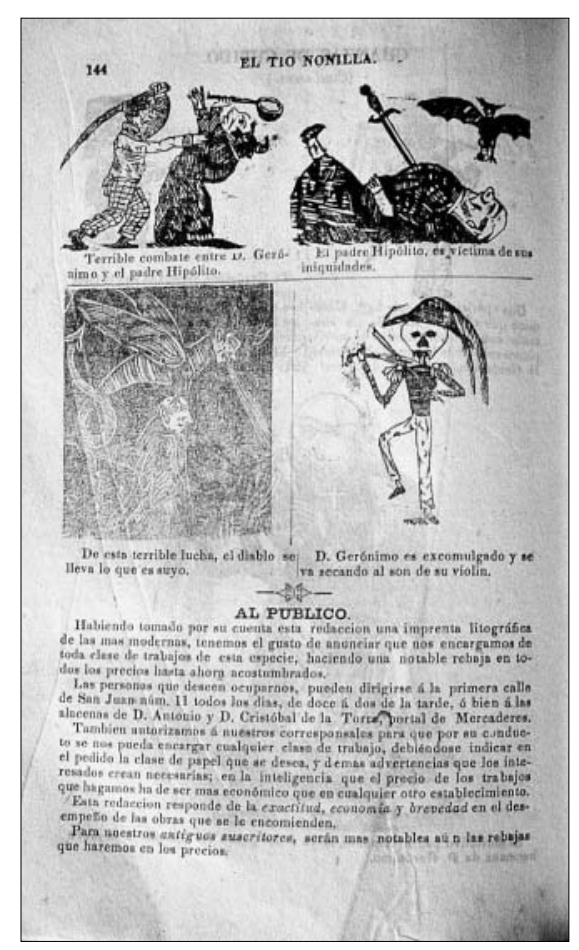

únicamente algunas partes, y resumo la historia: Cupido hace que el cesante don G erónimo se enamore de la rica y beata señora Callejas; ésta, que no es una beldad, emocionada se lo cuenta al padre $\mathrm{H}$ ipólito, el cual trata de disuadirla pues al casarse tendría que disminuir sus donativos a la iglesia. Al no conseguirlo, decide enamorarla, y empiezan sus disgustos con don Gerónimo. Un día éste encuentra al padre en una pulquería enamorando a una quinceañera, y furioso lo mete en un barril, en el cual el ejemplar cura casi muere, pero logra salvarse y vengarse de don Gerónimo. D espués, con las armas de la religión (una cruz en una mano y un puñal en la otra), hace que de una vez por todas la señora C allejas le done su fortuna. D e nuevo interviene Cupido (que en este caso tuvo que ser suplantado por una imagen del tiempo), y hace que el padre $\mathrm{H}$ ipólito se enamore de la hermana de don Gerónimo. Ambos luchan, y al morir el inicuo padre, el demonio se lo lleva. La historia concluye inesperada y bruscamente con las siguientes palabras, que corresponden a la imagen de un esqueleto que toca un instrumento de 
cuerda: D. Gerónimo es excomulgado y se va secando al son de su violín (figura 2). Vemos que, aunque Giménez no realiza las imágenes, se sirve de ellas para crear las ácidas historias que lo caracterizan; estos grabados en madera son muy toscos y en general poco atractivos, algunos de ellos muy afines a los que ilustraron ciertas modestas hojas volantes que circularon en M éxico durante las décadas de los treinta y los cuarenta. ${ }^{229}$

Es a partir del número 4 del 28 de septiembre de 1850 cuando se empiezan a publicar litografías aparte del texto (puesto que los métodos de impresión son diferentes), las cuales también se vendían sueltas, a dos reales cada una. 0 casionalmente, el retraso de las láminas incidió en el retraso de la propia publicación. ${ }^{130} \mathrm{D}$ e cualquier modo se continuarían alternando con los grabados xilográficos comprados tal vez a otras imprentas y algunos quizá prestados por Vicente García Torres, el editor de El M onitor Republicano, pues de la imprenta de éste salieron los primeros números del periódico de Giménez en su segunda época. Como empresa que iba prosperando, quizá con apoyo del gobierno, El Tío Nonilla anunció un mes después, el zo de octubre, haber tomado a su cargo una imprenta litográfica en la cual realizaba todo tipo de trabajos de esta clase, ofreciendo al público un precio rebajado, exactitud y brevedadi3i (se sabe ya que muchos de los editores de periódicos realizaban esta labor para incrementar sus ingresos).

Buena parte de las litografías están firmadas con las iniciales J.G.Z., que son las de Giménez; además, por el escándalo que desató una de ellas, éste se vio orillado a aceptar haber sido quien la dibujó, como se verá adelante. El escritor conocía el éxito que en España tenían los periódicos satíricos ilustrados, los cuales habían aparecido en la década de los treinta, y se irían generalizando en los cuarenta. Por ello es explicable que haya querido que su periódico tuviera imágenes, y que él mismo, a pesar de su poca habilidad, se hubiera arrojado a realizarlas. De nuevo sería un romántico europeo, como lo había sido Linati en relación con la litografía, uno de los que promovían la ilustración de periódicos en M éxico, aunque Giménez lo hacía en el género de la caricatura. Por otra parte, hay otras afinidades entre ambos: su interés

I29. Véase, por ejemplo, la que se titula Relacion del castigo orrendo que tubo un hijo desobediente que quiso matar á su padre, impresa en la calle de San Camilo núm. 9, colección Lafragua, vol. 422.

I30. "A nuestros lectores", en El Tío..., op. cit., 28 de septiembre de I85o, t. II, núm. 4, p. 49. I3I. "Al público", en El Tío..., op. cit., 30 de octubre de i850, t. II, núm. 9, p. i44. 
de viajeros, sus injerencias políticas, su expulsión y retorno a M éxico, más afortunado en el caso de Giménez.

El dibujo en la mayoría de las láminas es torpe y rígido; sin embargo, hay notorios desniveles entre ellas, y algunas están mucho mejor dibujadas que otras, lo que se debe quizá a que hubiera otra mano además de la de G iménez 0 a que fueron copiadas de los dibujos realizados por Tony Johannot para el libro Voyage où il vous plaira, como se mencionó antes. Al copiarlas, Giménez les añadía o quitaba sólo algunos elementos para adecuarlas a sus historias, y en este sentido no hacía al go muy distinto de cuando simplemente adquiría imágenes ya hechas.

Se mencionó que la mayoría de los textos literarios de EI Tío N onilla eran obras románticas españolas. Al copiar Giménez a Johannot, daba a su vez cabida en lo visual al romanticismo francés. Por lo que se refiere al propio Johannot, sus imágenes inspiraron a otros ilustradores mexicanos, incluso desde antes de la llegada de Giménez. ${ }^{132}$

En la temática de las caricaturas de El Tío N onilla predomina la sátira política, aunque posteriormente, cuando ya había triunfado Arista, las ilustraciones, lo mismo que los textos, se diversificaron. Entonces se copiaron retratos (de Garibaldi, por ejemplo), figurines de modas (tomados del Correo de U Itramar) y algunas ilustraciones de textos literarios; se publicó también la vista ya mencionada de una inundación provocada por el Río M ississipi.

Las caricaturas litográficas en general ilustran la sección fija titulada Cuadros animados, y son las que ofrecen mayor interés. Reflejan la postura política del periódico, y en general son muy fieles a los textos. Excepcionalmente, en los casos en que éstos describen escenas muy complejas, las ilustraciones no los siguen, y cobran cierta independencia. Es muy probable que en al gunas de ellas Giménez dé rienda suelta a resentimientos personales hacia Juan Suárez de N avarro, quien es el segundo personaje más caricaturizado en El Tío N onilla, siendo el primero Guadalupe Perdigón Garay, liberal puro pero también santanista. Cabe preguntarse si el español tuvo igualmente alguna razón personal para vengarse de este último, o si fue tan sólo el hecho

I32. Cabe señalar, por ejemplo, una imagen titulada el Ensueño del tirano, la cual circuló en una hoja suelta hacia i845 y forma parte de la colección de Rafael Barajas, quien la analiza en su libro, op. cit., pp. I40-I4I. I gualmente la imagen titulada $\mathrm{G}$ ol pe de estado, que apareció en el Calendario liberal de 1854 editado por Vicente Segura Argüelles. 
de que era enemigo político de Arista. Como sea, ambos hombres trabajaron arduamente por el regreso de Santa Anna.

A pesar de su declaración de neutralidad, en su segunda época El Tío N onilla apoya francamente, desde su primer número, la candidatura a la presidencia del general $\mathrm{M}$ ariano Arista, y ataca al resto de los contendientes, que eran Juan N. Almonte, Luis de la Rosa y Antonio López de Santa Anna. ${ }^{33}$ Esto se reflejará en las caricaturas, en las que Giménez también celebrará la victoria de Arista, y denunciará las conspiraciones de los derrotados y descontentos.

Varias de las caricaturas atacan a Juan N . Almonte. D os de ellas son xilografías, probablemente adquiridas: la primera se publicó el 29 de agosto de I850, en el número 2, y representa a Almonte, que, según el texto, tiene un voto: el suyo. El 28 de septiembre se publicó la otra, acompañada de un texto que dice que el niño Juan $\mathrm{N}$. Almonte, a los 3 años, ha ganado ya batallas famosas, y haciendo irónica alusión a su ascendencia y origen ilegítimo (Almonte era hijo de Morelos) añade: "loor eterno al congreso de C hilpancingo, que a los 9 meses de edad, lo honro con la faja de general". La tercera, que es ya una litografía, se publicó también para ridiculizarlo, el io de octubre de i850 (figura 3). La mujer que va a caballo representa a su hermana, y puesto que ella misma no puede ser presidenta, reparte boletas en las que el nombre de Almonte ya está escrito, para que los ciudadanos voten por él, y una vez elegido, ella logre tener influencia en el gobierno. En su empeño atropella a dos electores, y a uno le rompe la quijada; en compensación, les promete que si votan por su hermano, los hará generales, ministros o canónigos, o bien literatos o poetas, abogados $u$ hombres de talento. ${ }^{134}$

El licenciado Tlachique es el personaje más caricaturizado por Giménez. Se trata del liberal puro Guadalupe Perdigón Garay, quien fungió como diputado en $1847,{ }^{135}$ y fue también un activo partidario y promotor de Santa Anna. Junto con Suárez de $\mathrm{N}$ avarro, participaría desde i852 en los sucesivos planes que se dieron a conocer en Jalisco, y que terminarían Ilamando a

I33. D icha postura provocó que el periódico santanista EI Lancero acusara caballerosamente a El Tío N onilla de ser el órgano de la prensa de Arista más conceptuado y capaz, acusación que El Tío N onilla rechazó. "Al Lancero", en El Tío..., op. cit., 5 de septiembre de I85o, t. II, núm. 2, p. 30.

I34. "Cuadros animados", en El Tío..., op. cit., ro de octubre de i85o, t. II, núm.6, p. 85.

I35. Pedro Santoni, op. cit., p. 2 I2. 


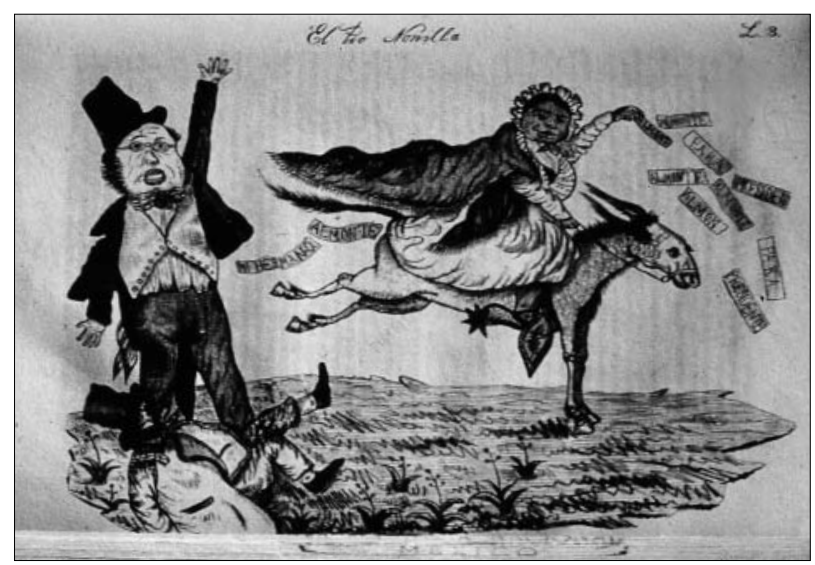

Figura 3. Joaquín Giménez, caricatura que ilustra la sección "C uadros animados", en El Tío $\mathrm{N}$ onilla, io de octubre de I850, t. II, núm. 6, entre las páginas 84 y 85, I2.7 X I8.5 cm, Fondo Reservado de la $\mathrm{H}$ emeroteca $\mathrm{N}$ acional de $\mathrm{M}$ éxico. Foto: $\mathrm{H}$ EBR.

Santa Anna y haciendo renunciar final mente, a principios de 1853 , a Arista. ${ }^{136}$ El historiador González N avarro lo describe como un popular federalista, con cuerpo de Sancho Panza y espíritu de Don Q uijote. ${ }^{137}$ Según Andrés Lira, Perdigón Garay fue, como algunos otros, un agitador que aprovechó los conflictos sociales (en particular los derivados de las tierras comunales) para presionar al gobierno moderado y para atacar a los conservadores. Este hombre se llamó a sí mismo "abogado del pueblo", pues estaba en contacto con las "clases ínfimas" de la sociedad" indios de pueblos y barrios, vagos y malvivientes procesados en la cárcel de la ex Acordada. D e hecho, cuando en sus inicios el gobierno de Herrera expidió una ley sobre el modo de juzgar a ladrones, homicidas y heridores, en ella se estableció la existencia de defensores de oficio, cargo que Perdigón G aray desempeñó con entusiasmo. Cuando Arista, siendo ministro de Guerra, lo encarceló y desterró a Izúcar de $M$ atamoros, en Puebla, se fugó afirmando que en un lugar tan pequeño no podría ejercer su profesión. ${ }^{138}$ Estando en la prisión Perdigón Garay gozó de

136. Carmen Vázquez M antecón, Santa Anna y la encrucijada del Estado. La dictadura ( 1853 I855), M éxico, Fondo de Cultura E conómica, 1986, pp. 28-36.

137. G onzález N avarro, op. cit., p. I6I.

138. Andrés Lira, Comunidades indígenas frente a la ciudad de M éxico: Tenochtitlan y Tlatelolco, sus pueblos y barrios, I8I2-I9I9, Zamora, El Colegio de M éxico-El Colegio de M ichoacán, 1983, pp. I43-I44, I5I-152, 168. 


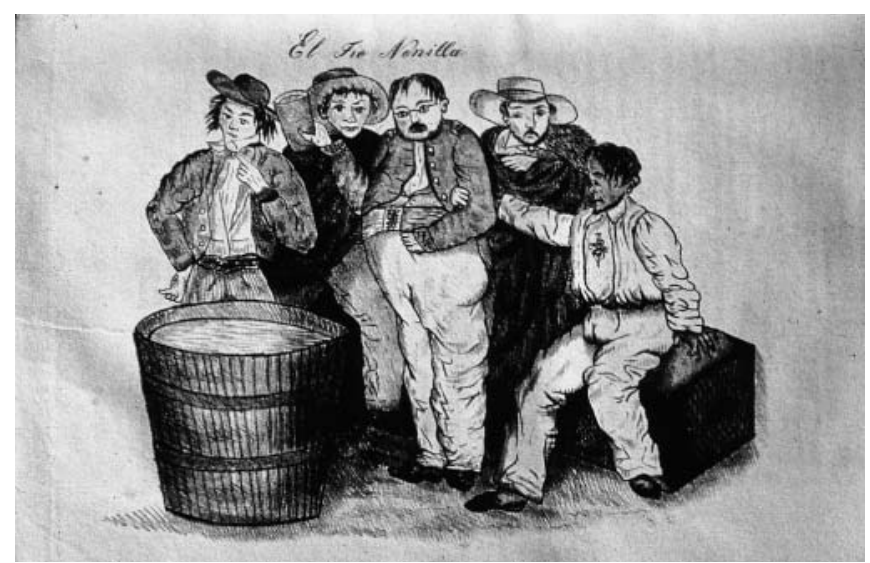

Figura 4. Joaquín Giménez, caricatura que ilustra la sección "Cuadros animados", en El Tío $\mathrm{N}$ onilla, 28 de septiembre de I850, t. II, núm. 4, entre las páginas 58 y $59,11.5 \times 16.3 \mathrm{~cm}$, Fondo Reservado de la H emeroteca $\mathrm{N}$ acional de M éxico. Foto: HEBR.

poder entre los reos; irónicamente, El Tío N onilla dice que éstos le llamaban papá. Como todo caricaturista, Giménez se prendió de uno de los grandes defectos de este personaje: su afición a la bebida, probablemente al pulque. ${ }^{139}$ En la primera imagen que le dedicó (figura 4 ) aparece rodeado de criminales en la cárcel de la ex Acordada. Está ebrio, y se sostiene el pantalón con una mano mientras brinda con un vaso de pulque, que cada vez que es necesario Ilena en una patriótica tinaja. A Caimán, quien lo sostiene por el costado izquierdo, le dice que le esperan grandes hazañas en los bosques de Río Frío. Entre vivas al gran papá de los probes, T lachique continúa, y a Aguacate le dice: a ti, "que con tanto cariño me metes la rodilla por la parte trasera... a tí terror de las cerraduras y las trancas... te aguarda dichoso destino en las calles de M éxico". Finalmente, T lachique acaba cayéndose, vomitando espirituosa

139. Rueda Smithers, op. cit., p. 333, señala que durante la campaña a la presidencia de Arista se publicó en su contra un periódico titulado El Tlachique, que calificó a Arista de bribón. Sin embargo, el autor no precisa cuál fue la fuente de donde obtuvo este dato, y parece más bien que se trata de una ligera confusión, pues, por el orden en que cita la información, es casi seguro que dedujo lo anterior de una nota publicada en EI T ío N onilla titulada "El foragido Perdigon (a. Lic. Tlachique)", en El Tío..., op. cit., 2 de octubre de I85o, t. II, núm. 5, p. 69, en la que se dice que entre los papeluchos que habían circulado en los últimos días, había uno del forajido Perdigón en contra de que se votara por Arista; el redactor comentaba que un ataque de ese perdido (Perdigón) era en realidad un elogio. 
sangre, y gritando “¡M uera Arista!" ${ }^{140} \mathrm{H}$ ay que recordar que Andrés Lira piensa que quizá el licenciado Bedolla, uno de los personajes de L os bandidos de Río Frío, la novela de M anuel Payno, representa justamente a Perdigón Garay. Bedolla era uno de los protegidos de Pedro M artín de O lañeta (Lira lo identifica con el puro Francisco M odesto de O laguíbel). ${ }^{.4 \mathrm{I}} \mathrm{C}$ abe apuntar, en apoyo de lo dicho por Lira, que cuando el santanista Juan Yáñez (el Relumbrón de la novela de Payno y jefe de los bandidos de Río Frío) fue procesado en I839, Perdigón Garay trató de encubrirlo en una de sus coartadas. ${ }^{142}$ Por otro lado, las burlas de Giménez también lo incriminaban, pues le llamó "papá de los habitantes de los bosques de Río Frío y demás caminos y encrucijadas". ${ }^{43}$ Como sea, habían transcurrido ya once años desde que Yáñez y varios de los criminales que comandaba habían sido detenidos y ejecutados.

En otra caricatura, publicada el io de octubre y que acompaña al artículo "U na nueva fatal", un escribano va a ver al prófugo Tlachique, quien horrorizado deja caer el vaso de pulque y una silla, al recibir la noticia de que Arista ganó las elecciones. ${ }^{144}$ Tlachique aparece también en otra imagen en que $\mathrm{El}$ Tío N onilla celebra la derrota de Santa Anna y Almonte (figura s): el Tío se sueña muerto, y desde su tumba ve un rico mausoleo con una inscripción dorada que dice " $A$. Q . Y. [aquí yacen] las esperanzas de Santa-Anna, Almonte y comparsa." Arriba ve una especie de murciélago, que es el espíritu de T lachique. M ás arriba aparece EI Lancero, periódico santanista representado por su director el coronel Cabrera (según el texto, revolotea como una lechuza, sobre una nubecilla, aunque más bien lo vemos volando sobre una escoba, como una bruja), quien le dice al Tío que está velando por las esperanzas de sus hé roes, y que representa la fuerza y la justicia (simbolizada por la bal anza que, se-

I40. "Cuadros animados", en El Tío..., op. cit., 28 de septiembre de i85o, t. II, núm. 4, pp. 58-59.

I4I. Lira, op. cit., p. i68.

I42. Tomás de Castro y Antonio Alvarado, Extracto de la causa formada al ex-coronel Juan Yáñez y socios, por varios asaltos y robos cometidos en poblado y despoblado, que para satiffacción del público dan a la luz los fiscales que la han instruido, M éxico, Imprenta de Galván, I939, reproducido en Felipe Gálvez et al., Los verdaderos bandidos de Riofrío, za. ed., M éxico, Ediciones y D istribuciones H ispánicas, 1987.

I43. "U na conjuración monarquista. Poema cáustico en cuatro cantos en verso, y epílogo en prosa, adornado con cuatro láminas", en El Tío..., op. cit., sin fecha, t. II, suplemento del núm. I6, sin número de páginas. No tiene fecha, pero debió publicarse el 2i de diciembre de I850, según se señala en el número siguiente.

I44. “U na nueva fatal”, en El Tío..., op. cit., so de octubre de i85o, t. II, núm. 6, p. 92. 


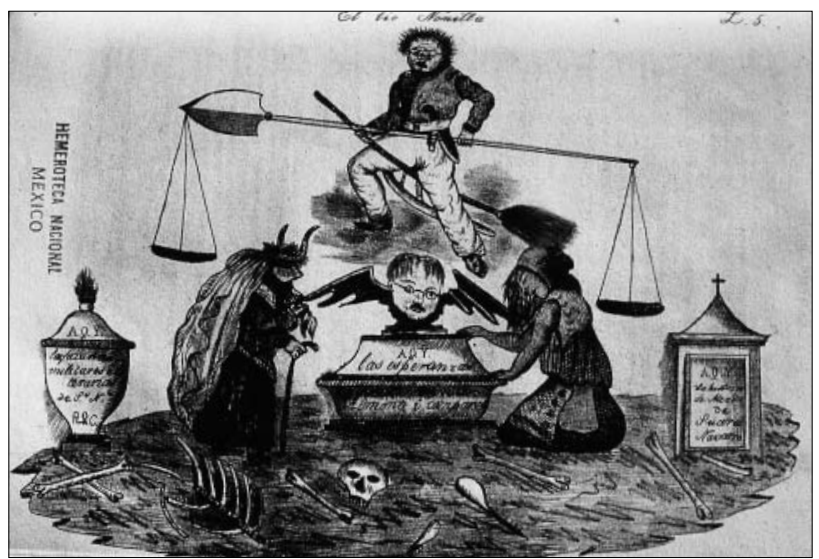

Figura 5. Joaquín Giménez, caricatura que ilustra la sección "C uadros animados", en El Tío $\mathrm{N}$ onilla, I7 de octubre de i850, t. II, núm. 7, entre las páginas iıo y iı (la numeración está equivocada, y algunos números de páginas se repiten; esta imagen en el original es la L. 5, 0 lámina 5, y en ella aparece en la parte superior un personaje con una balanza), $13.5 \times 19.4 \mathrm{~cm}$, Fondo Reservado de la H emeroteca $\mathrm{N}$ acional de M éxico. Foto: H EBR.

gún el Tío, es como el yelmo de M ambrino, que presuntamente usaba D on Quijote). En uno de los lados está un pequeño sepulcro que dice "A.Q.Y. la H istoria de M éxico de Suárez de N avarro" (porque éste escribió una historia para alabar a Santa Anna) y en el otro "A.Q.Y. las fazañas militares y literarias de Suárez de N avarro". ${ }^{45}$ U na de las más conocidas es la estampa en que aparece T lachique con cuerpo de tonel y sus acostumbradas alas de murciélago. EI Tío aclara haberle encontrado así, en el camino a Tacubaya, hurtando el aguamiel a un indio, el cual le pregunta que cuándo dejará de vivir del sudor de los infelices, mientras Tlachique le contesta que está en su derecho, por ser papá del pueblo y por ser socialista. ${ }^{46}$ Por tanto, El Tío N onilla, acorde con lo que afirma Andrés Lira, acusaba implícitamente a Perdigón de medrar a expensas de los problemas de los indios respecto a las tierras comunal es ${ }^{\mathrm{T} 47}$ (en este tiempo los propietarios acusaron a los comuneros de socialistas). ${ }^{48}$

I45. "Cuadros animados", en El Tío..., op. cit., i7 de octubre de i850, t. II, núm. 4, p. iıo.

I46. "C uadros animados", en El Tío..., op. cit., 30 de octubre de ı850, t. II, núm. 9, p. I33.

147. Lira, op. cit., p. i59.

I48. La retórica política se modernizaba y universalizaba los sucesos locales en la manera de describirlos, por ello hablaba de "socialismo" en relación con los pueblos comunalistas. El fantasma de la igualdad asustó incluso a los liberales más destacados como M ora, quienes impug- 


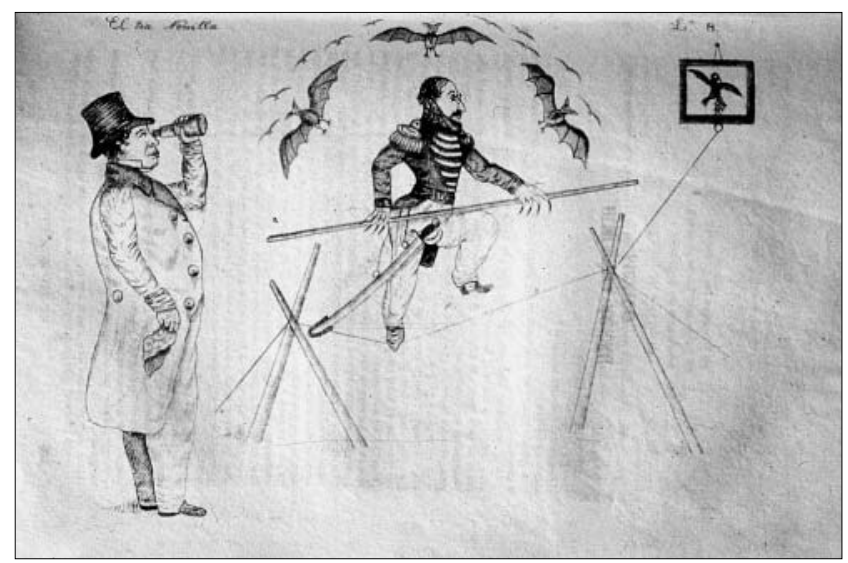

Figura 6. Joaquín Giménez, caricatura que ilustra la sección "Cuadros animados", en El Tío $\mathrm{N}$ onilla, 24 de octubre de I850, t. II, núm. 8, entre las páginas I20 y I2I, I2.5 X I6.4 cm, Fondo Reservado de la $\mathrm{H}$ emeroteca $\mathrm{N}$ acional de $\mathrm{M}$ éxico. Foto: $\mathrm{H}$ EBR.

La caricatura que se publicó en el número 8 , el 24 de octubre de i850 (figura 6), causó revuelo por la reacción que provocó. En ella aparecen un tal Gutiérrez, quien lleva un anteojo en mano, y el coronel García y García, quien entonces fungía como diputado, y que camina sobre una cuerda intentando realizar una maroma política, que lo hará caer al suelo. El Tío N onilla los acusó a ambos de estar involucrados, junto con otros personajes, en una revolución. Cuando García y García se vio caricaturizado, se puso furioso y fue de inmediato a la imprenta a pedir cuentas. Según explicó él mismo en un texto que publicó El U niversal, ${ }^{449}$ habló con Giménez, y éste aceptó haber escrito el artículo y haber dibujado la caricatura, pero le aclaró que la idea le fue sugerida por un tal teniente coronel Junguito (un opositor de Santa Anna), ,5o y que por tanto era él quien debía responder. García y

naron la rousseauniana "voluntad general" convirtiéndola en antítesis del orden y los derechos individuales. La guerra de castas y los sucesos de Europa en i848 acrecentaron el miedo a la igualdad que se equiparaba al caos. Rueda Smithers, op. cit., pp. 33 y 224-225.

I49. "Exposición", en El U niversal, op. cit., 3 de noviembre de I850, t. Iv, núm. 718, p. 2.

I50. J unguito fue acusado de difamación por Suárez de $\mathrm{N}$ avarro, a quien disgustó un artículo que el primero publicó en El M onitor Republicano el 31 de agosto de I850, y cuyo título era "Reflexiones sobre la retirada de la Angostura". V éase Rafael Junguito, Contestación al alegato presentado por D. Juan Suárez de N avarro en la causa instruida al teniente corone D. Rafael J unguito, por difamación, M éxico, imprenta de Vicente G arcía T orres, a cargo de L. Vidaurri, I85o. 
García retó a Junguito a duelo, y éste aceptó, pero le dijo que arreglara el asunto con el señor Anselmo $\mathrm{C}$ ano. Finalmente el diputado discute con $\mathrm{Ca}$ no y termina hiriéndolo. El caso se llevó a la Cámara de D iputados, dado el cargo de García y García, quien leyó ahí su defensa y atacó y calificó de libelo a El Tío N onilla. Se leyó también el ejemplar en el que había aparecido la caricatura, y se dio lugar a causa. No obstante, desde la cárcel, Giménez desmintió la versión de García y García, señalando que Junguito nunca había participado en el periódico, ni siquiera indirectamente, y que el propio Giménez le había respondido al injuriado que, como jamás lo había visto, no era posible que hiciese su caricatura, sino que eran buenos amigos quienes le proporcionaban las de las personas que no conocía, y entre ellas no se encontraba Junguito. ${ }^{\text {I5I }}$

Los hechos anteriores hicieron que al gunos de los periódicos enemigos de El Tío N onilla pidieran su prohibición. Para fortuna de éste, el lance le trajo, según sus propias palabras, un aumento increíble en la lista de suscripciones. Provocó también que la oposición intentara promover un proyecto de ley que prohibiese las caricaturas. Esto pareció absurdo al Tío, pues pensaba que una ley de esta naturaleza desde el principio sería impunemente burlada mediante algún subterfugio: por ejemplo - decía, y lo ejemplificaba con una imagen (figura 7) - , pintar una figura cualquiera que no pareciera hombre para que no fuese posible decir que se trataba de Suárez de Navarro, que llevara un libro inmenso (la H istoria del general Santa Anna, por ser muy malo) con candado, en señal de que nadie lo había de abrir. No se le podría acusar a El Tío N onilla de haber hecho una caricatura del historiador Suárez de Navarro, por más que el avechucho cargara su libro, y él sería muy bobo si encontrara alguna semejanza entre la pintura y su persona. Afirmaba por lo tanto que mientras no se suprimiera la ley de imprenta, cualquier ley sería inútil para impedirle que publicara sus caricaturas. ${ }^{152}$

La respuesta de EI Tío N onilla es ingeniosa: en la ilustración correspondiente ${ }^{153}$ indudablemente el personaje es Suárez de $\mathrm{N}$ avarro, no sólo por el libro y por la cara (que es la misma con que lo representaría en otras carica-

I5I. "Gran Jurado", en El T ío..., op. cit., 7 de noviembre de i850, t. II, núm. Io, p. I5I.

I52. "C aricaturas", en El Tío..., op. cit., 7 de noviembre de ı850, t. Iı, núm. ıo, pp. I59-ı60.

I53. Esta caricatura de Suárez de N avarro guarda una afinidad que quizá no sea casual con una imagen realizada por Grandville en I844 para su obra U n autre monde, en la que aparece un personaje vestido de forma muy similar y con patas semejantes en la forma a las de la imagen de El Tío N onilla, G randville, 0 tro mundo, Barcelona, H esperus, i988, p. xxix. 


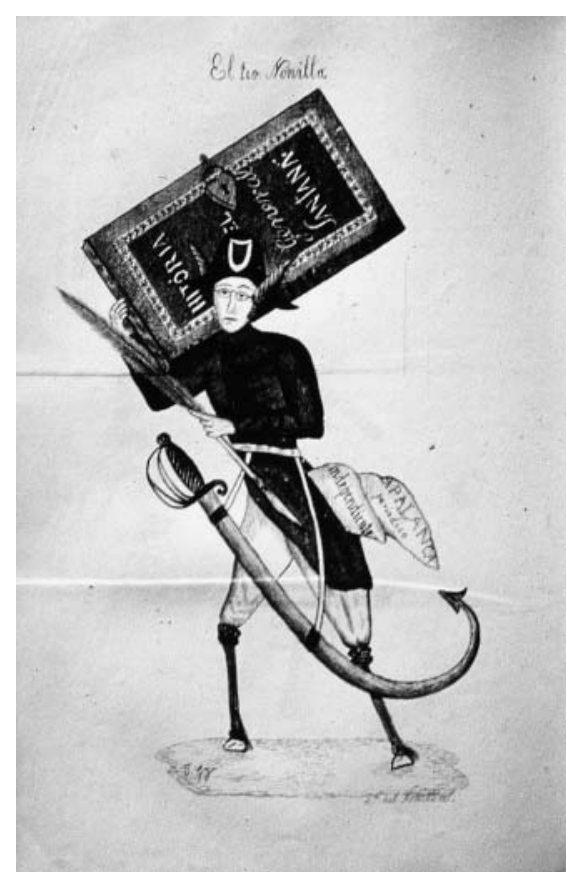

Figura 7. Joaquín G iménez, caricatura que ilustra el artículo "C aricaturas", en El Tío N onilla, 7 de noviembre de i850, t. II, núm. Io, se ubica antes de la página 159 (un personaje con patas de burro carga un libro que dice $\mathrm{H}$ istoria del general Santana), I6.8 x io.I cm, Fondo Reservado de la $\mathrm{H}$ emeroteca $\mathrm{N}$ acional de $\mathrm{M}$ éxico. Foto: HEBR.

turas), sino porque la pluma nos dice que se trata de un escritor y porque en el papel que sale de su bolsa está escrito el nombre del periódico La Palanca, el cual editabais4 (y en el que Perdigón Garay llegó a colaborar). 155 Probablemente este hecho fue el que provocó que se sentenciara a seis meses de reclusión a Giménez, y que José Casanova, el otro redactor, abandonara la publicación, según se anunció en el número del 2i de noviembre. ${ }^{156} \mathrm{No}$ obstante, El Tío N onilla se continuó publicando sin interrupción con todo e

I54. En el anónimo "Remitido", en Gacetilla del M onitor, 3 de agosto de I85o, núm. 3, p. 3., se afirmaba que en La Palanca no sólo escribían Suárez de N avarro y [Juan] García Brito, pues al ser denunciados al gunos artículos difamatorios de dicho periódico había resultado que sus supuestos autores eran en realidad "firmones" que prestaban su nombre para que ocultos tras ellos otros escribieran.

I55. "El Sr. Perdigón Garay ", en El Tío..., op. cit., 24 de octubre de ı850, t. II, núm. 8, p. iı2. 156. Sin embargo, Casanova continuó en M éxico por lo menos algún tiempo, pues el 2I de enero de i85I se anunció en EI M onitor Republicano que en el Teatro $\mathrm{N}$ acional se estrenaría la obra U n rasgo del rey doliente, escrita en La H abana por el propio José Casanova (a quien se reputaba como muy conocido por sus producciones literarias) y por el cubano Joaquín García. 
ilustraciones. Q uizá G iménez continuaba realizando los originales de textos e imágenes en la cárcel, y de ahí los enviaba al impresor; lo que es evidente es que, de ser así, tuvo otros colaboradores, a pesar de que en el número del 2I de noviembre se señalaba que había quedado como único redactor. ${ }^{157}$ No se sabe el tiempo que en realidad duró la condena, o si fue sólo un subterfugio para calmar las protestas de sus colegas, el caso es que este defensor del partido gobernante se encontraba sin duda libre en febrero (cuando, como se ve adelante, fue retado a duelo por un poeta cubano), y muy probablemente desde mucho antes, dadas la ininterrupción del periódico y la aparición de una nueva publicación redactada por él.

El ya citado historiador jalisciense Suárez de N avarro fue blanco continuo de las burlas de El Tío N onilla. Es el personaje zoomorfo que aparece a la izquierda en la caricatura que se publicó en el número 5 , el 2 de octubre de I850, en la que Giménez lo representa aconsejando precisamente a Santa Anna (el de la pata de palo) y a sus generales en el momento en que discuten sobre cómo hacer la defensa del país ante la invasión norteamericana, ocurrida tres años atrás. Suárez les propone, supuestamente conforme a lo que haría N apoleón, modelo de Santa Anna, que para evitar mayor derramamiento de sangre apuesten sus tropas en los puntos en los que haya menor probabilidad de que ataque el enemigo. Santa Anna hace la repartición de ellas, y sólo pide que le dejen dos docenas de caballos, de los más "correlones" del ejército. D e todas las "corridas" se le dará parte a Suárez de $N$ avarro para que pueda narrar sus hazañas. El enemigo toma la capital sin hechos sangrientos. Gracias a Suárez de N avarro, quien con graznidos de avestruz canta las hazañas del "corredor de Padierna" y chupa el precio de ello, Santa Anna fue postulado presidente y ha obtenido un octavo de voto en las elecciones presidenciales ${ }^{158}$ (el tema de la invasión, por otra parte, campea a lo largo de EI Tío N onilla, pues la herida por la pérdida del territorio fue muy profunda y estaba muy reciente).

Al final, los ataques de El Tío N onilla se dirigen a los monarquistas y clericales redactores de EI U niversal, y principalmente a Lucas Alamán, pero también a algunos santanistas y al puro Perdigón Garay. ${ }^{159}$ En la imagen,

I57. "Al público", en El Tío..., op. cit., 28 de noviembre de I850, t. II, núm. I3, p. 192.

I58. "Cuadros animados", en El Tío..., op. cit., 2 de octubre de i85o, t. II, núm. 5, p. 73.

I59. González $N$ avarro señala que desde el principio el gobierno de Arista fue combatido por el partido conservador, por una parte del puro, por los santanistas y por los militares a quienes siendo ministro de Guerra dio de baja. En realidad, este combate se había iniciado 


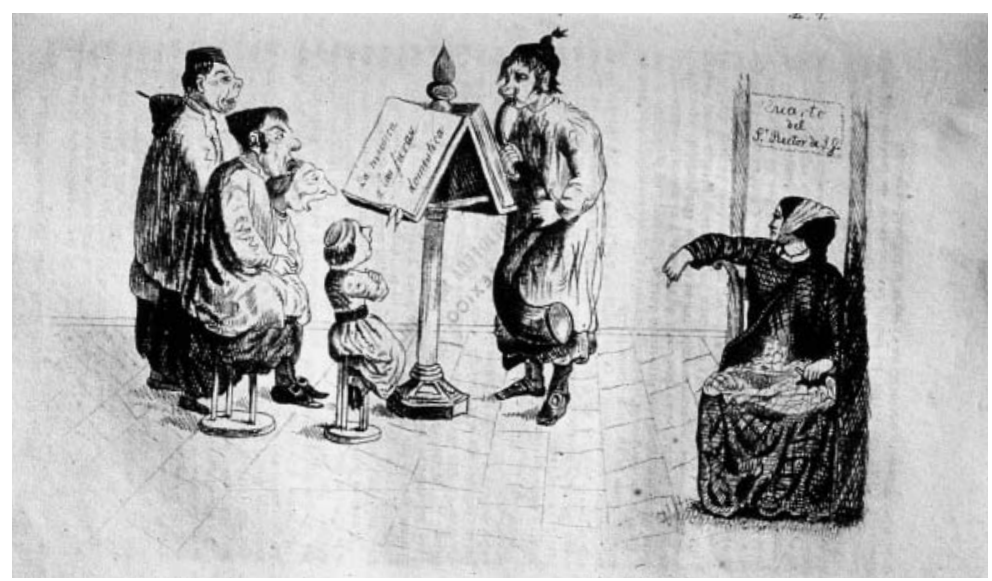

Figura 8. J oaquín Giménez, caricatura que aparece en El Tío N onilla, 24 de octubre de 1850 , t. II, núm. 8, entre las pp. iıo y iII (la numeración está equivocada, y algunos números de páginas se repiten; esta imagen en el original es Ia. L. 7, o lámina 7, y en ella aparece un sacristán que dirige un coro), ir.9 x $17 \mathrm{~cm}$, Fondo Reservado de la $\mathrm{H}$ emeroteca $\mathrm{N}$ acional de M éxico. Foto: HEBR.

publicada el 24 de octubre de i850 (figura 8), vemos cómo satiriza al doctor D íez de Sollano, cura y director del colegio de San Gregorio, quien - diceha organizado un escuadrón anti-diablos o Guardia de honor de las santas escamas, ${ }^{160}$ y en las noches ensayan sus himnos antirrepublicanos y santanistas. El hecho de que una joven se encuentre en el cuarto del religioso implica, desde luego, un comentario mordaz.

Las últimas cuatro caricaturas publicadas en El Tío Nonilla aparecieron en un suplemento al número I6, en diciembre de I85o. Ilustran el texto titulado U na conjuración monarquista, poema cáustico, ${ }^{161}$ que incita al pueblo al linchamiento sangriento de Lucas Alamán, Rafael Rafael, Guadalupe Perdigón Garay, Antonio H aro y Tamariz (ex ministro de Hacienda de Santa

desde la candidatura de Arista, como se ve a lo largo de los contraataques en EI Tío N onilla. González N avarro, op. cit., p. 215.

I6o. Desde i849, El M onitor Republicano llamaba a El U niversal el periódico de las santas escamas porque éste había anunciado como prodigio un pez de llamativas escamas que se había encontrado en el colegio de San Gregorio.

I6r. Circuló en cuadernillo, bajo el título Aguinaldo a los monarquistas, según se indica en La Prensa, que, como se ve adelante, fue la posterior y efímera publicación de Giménez. "Anuncios", en La Prensa, 8 de febrero de i85I, t. I, núm. I7. 


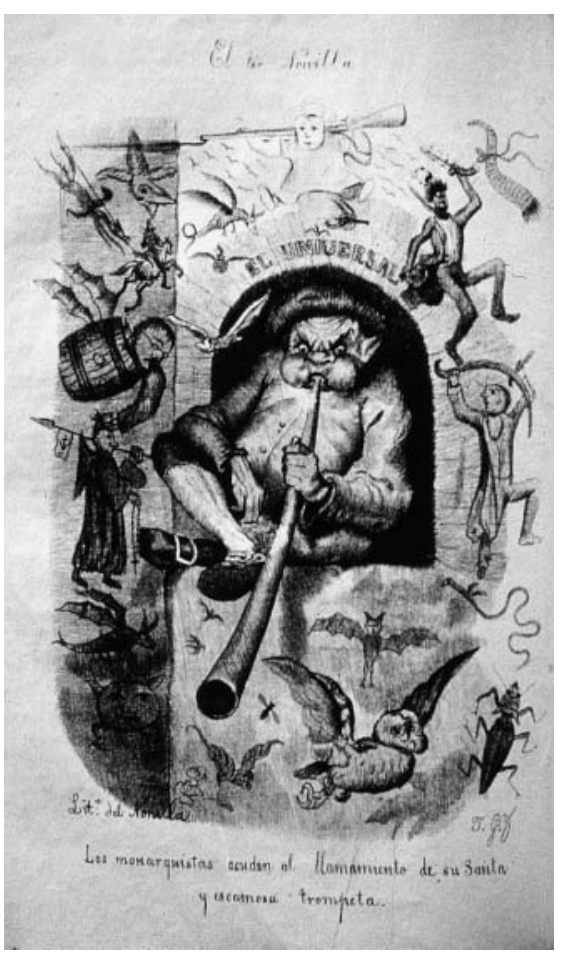

Figura 9. J oaquín Giménez, L os monarquistas acuden al Ilamamiento de su Santa y escamosa trompeta, caricatura que ilustra el Canto I de U na conjuración monarquista, poema cáustico, en El Tío N onilla, sin fecha, t. II, suplemento del núm. i6, sin número de página (no tiene fecha, pero debió de publicarse el 2i de diciembre de i850 según se señala en el número siguiente; es la primera imagen del suplemento, en ella aparece un personaje que toca una trompeta sentado en un nicho), $15.5 \times$ II.2 $\mathrm{cm}$, Fondo Reservado de la $\mathrm{H}$ emeroteca $\mathrm{N}$ acional de M éxico. Foto: HEBR.

Anna), Tagle, Pacheco, Almonte, Ampudia, Blanco y Gutiérrez, y concluye diciendo lo siguiente: "Pueblo, la sangre de estos infames es estiércol que necesita tu sagrado árbol" para que acabe la esclavitud y tiranía. ${ }^{162}$ Aunque en la lista no incluye a su odiado Suárez de N avarro, éste sí aparece en el poema y en dos de las ilustraciones.

Para hacer la primera caricatura (figura 9), Giménez copió (quizá calcó) literalmente una de las imágenes de Johannot (figura io),, ${ }^{163}$ y sólo le añadió algunos elementos para darle el sentido que quería. En ella el extravagante vigía dibujado originalmente por el ilustrador francés se convirtió en El U niversal, que convoca con su trompeta a una rebelión contra el gobierno republicano. A su alrededor revolotean varios bichos pequeñitos: Tlachique,

I62. U na conjuración monarquista, poema cáustico, en El Tío..., op. cit., sin fecha, t. II, suplemento del núm. i6, sin número de páginas. No tiene fecha, pero debió publicarse el 2i de diciembre de i850, según se señala en el número siguiente.

I63. M usset, op. cit., p. 29. 
Figura io. T ony J ohannot, ilustración del texto de M usset titulado Viaje a donde se os antoje publicado en i843; el ejemplar propiedad de Ricardo Pérez Escamilla se encuentra en el M useo N acional de Arte.

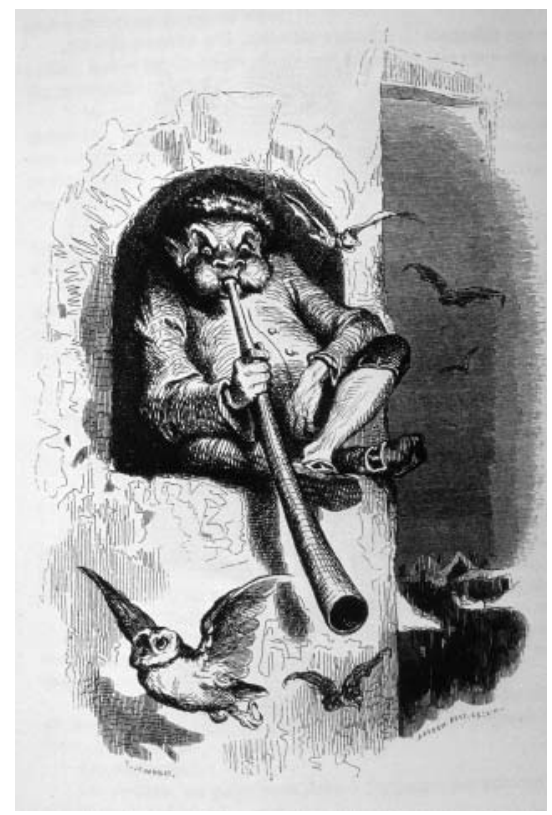

Foto: HEBR.

un fraile, algunos revoltosos con armas en las manos, un murciélago, insectos, serpientes y seres híbridos. D os de estos detalles (el jinete y el conspirador que lleva la pistola y una soga al cuello) fueron tomados de otras imágenes del artista francés, ${ }^{164}$ Tlachique es de inspiración nonillesca, y tal vez también lo sean los otros elementos. En general contrasta en esta caricatura la mejor resolución del dibujo de la parte que Giménez copió con la torpeza de la mayoría de los elementos añadidos.

El texto que acompaña esta primera caricatura es el siguiente:

Los planes del combate
dará EL U N IVERSAL....
todos sus redactores
las armas cogerán
y les guiará sus pasos
D. Lu CAS ALAM ÁN ...

I64. Ibidem, pp. Iо3 y i17. 


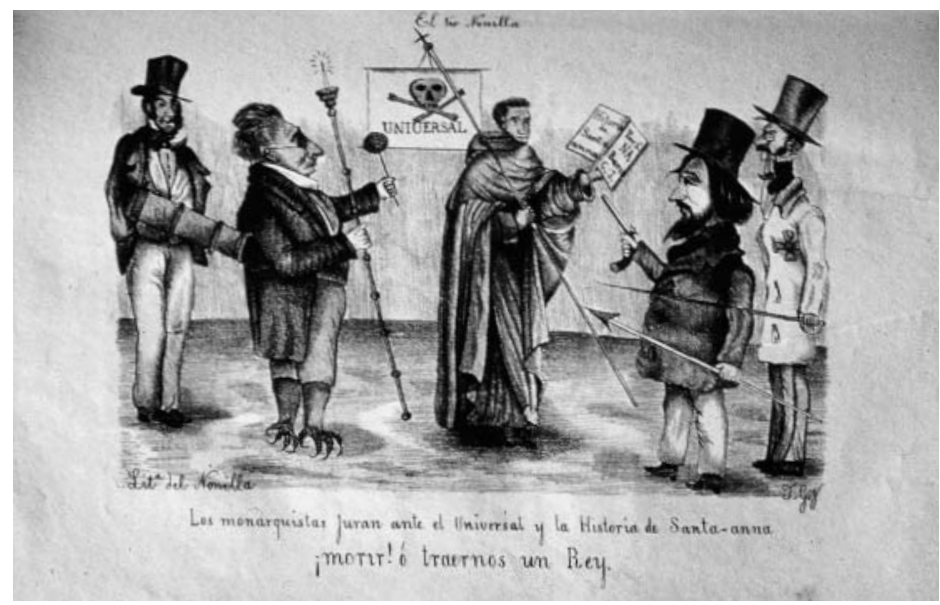

Figura II. Los monarquistasjuran ante el U niversal y la H istoria de Santa-anna jmorir! ó traernos un Rey, caricatura que ilustra el Canto in de U na conjuración monarquista, poema cáustico, en EI T ío N onilla, sin fecha, t. II, suplemento del núm. I6, sin número de página (no tiene fecha, pero debió publicarse el 2I de diciembre de I85o, según se señala en el número siguiente). Foto: H EBR.

La imagen que ilustra el segundo canto también fue tomada de Johannot, ${ }^{165}$ y Giménez sólo le hace pequeñas modificaciones para que ahora represente a los monarquistas, que se atropellan unos a otros para delatarse entre sí. Sin embargo, los rostros no han sido modificados, por lo que es claro que a Giménez no le preocupa necesariamente representar la fisonomía de quienes ataca. Por otra parte, dada su torpeza en el dibujo, tuvo poco éxito para caracterizar fisonomías.

La tercera caricatura se titula Los monarquistas juran ante el U niversal y la H istoria de Santa-anna jmorir! ó traernos un Rey (figura II). En ella aparecen los monarquistas y redactores de EI U niversal tomando las armas para alterar el orden. Uno de ellos, tal vez Lucas Alamán, presenta garras en lugar de pies, y tiene en la mano un hisopo y un cirial. El personaje que lo mira de frente, y que coge una pistola, podría ser el director de EI U niversal, Rafael Rafael, según lo describe Guillermo Prieto. ${ }^{166}$ El personaje vestido de fraile que lleva la historia de Suárez de $\mathrm{N}$ avarro debe ser el propio historiador, al que se le reprocha su alianza con los conservadores.

I65. Ibidem, p. i2I.

I66. Según el célebre escritor mexicano, Rafael Rafael era "de cabello cerdoso y tupido, barba recia, nariz romana, ancha espalda, piernas fornidas..." H enry Lepidus, "H istoria del 
El C anto IV, el último, se titula D e como los conjurados monarquistas desaparecen como el humo á la sola presencia de un agente del gobierno. La imagen que lo ilustra resulta divertida a pesar de su sangrienta intención, y en ella los conjurados se esconden en los trastos de una cocina. El texto dice al go sobre los personajes que aparecen en ella: el que está en el fogón es José I gnacio Trigueros: ${ }^{167}$ Suárez de N avarro está escondido en su libro de historia, Ilorando sus ambiciones y esperanzas; Perdigón, el flamígero, en un tonel ensayaba "al gunos viajes aereos, / de líquido y aire falto". Alamán no aparece aquí pues según el canto lo encontraron "cual lechuza / una lámpara chupando / en una de las iglesias". El pez que está colgado de la pared, a cuyo lado aparece la leyenda de las milagrosas escamas, representa a EI U niversal. ${ }^{168}$ Por otra parte, no todos los personajes corresponden necesariamente a personas reales, pues la cara más grande, que asoma del cazo ubicado casi en el centro, fue también copiada de una imagen de Johannot. ${ }^{169}$

El 26 de diciembre de i85o, en el número i7, El Tío N onilla anuncia que el segundo tomo ha sido concluido. Dice que va a dormir unos días, y que reaparecerá a mediados de enero, con mejoras: un formato mayor, una tipografía más clara, un precio más accesible, y mayor uniformidad en la impresión y en las ilustraciones. Aunque siempre negó ser órgano de la prensa aristista y que su periódico fuera sostenido por M ariano Arista, ministro de Guerra, ahora se declara satisfecho de haber colaborado en el triunfo de éste, con quien dice tener amistad personal.

Giménez reapareció en la arena periodística como lo había prometido, y nuevamente se vio envuelto en dificultades ocasionadas por sus críticas. El 29 de enero de ${ }^{8} 85 \mathrm{I}$ Juan M iguel de Losada, poeta y dramaturgo habanero, ${ }^{170}$ publicó un remitido defendiendo su reputación. D ecía que el español lo había calumniado en La Prensa, periódico sucesor de El Tío N onilla, por lo

periodismo mexicano", en Anales del M useo $\mathrm{N}$ acional de Antropología, H istoria y Etnología, M éxico, 1927, 4a. época, t. v, p. 42I.

ı67. Trigueros fue un acendrado santanista; en ı847, al regreso de Santa Anna a la capital, él quedó como gobernador del D istrito Federal. Pedro Santoni, op. cit., p. 194.

I68. Véase la nota i6o.

I69. M usset, op. cit., p. 9I.

I70. Losada tuvo un cargo militar en el ejército mexicano, a pesar de ser cubano de nacimiento. El 20 de enero de I850 estrenó en el T eatro $\mathrm{N}$ acional su primera obra escrita en M éxico, la cual se tituló El grito de D olores y fue además la primera puesta en escena que utilizó este tema. A la representación asistieron el presidente H errera y sus ministros. Luis Reyes de la M aza, op. cit., p. 8o. 
cual él lo había retado a duelo; llegado el momento de batirse, Giménez se había retractado y había jurado no haber escrito el artículo; sin embargo, después se había jactado de ser el héroe del asunto. Losada decía haberlo vuelto a retar, pero como Giménez no aceptaba, se veía obligado a hacer público el asunto. ${ }^{771} \mathrm{La}$ Prensa, ${ }^{172}$ el nuevo periódico del Tío N onilla, estuvo escasamente ilustrado (sólo hay dos láminas litográficas en el ejemplar que se conserva; una es un anuncio para un cajón de ropa, y la otra un globo aerostático), a pesar de que, como se mencionó antes, el escritor supuestamente ya contaba con una prensa litográfica. Finalmente, Giménez no pudo cumplir sus deseos de mejorar su publicación, no sólo con respecto a las ilustraciones, sino tampoco en cuanto a la tipografía (que seguía siendo muy pequeña para ocupar menos papel); y aunque en efecto el periódico aumentó su tamaño, redujo el número de sus páginas. Cabe mencionar también que, para allegarse recursos, Giménez continuó vendiendo la colección completa de la segunda época de EI T ío N onilla, ${ }^{173}$ señalando que contenía intercaladas 42 láminas litografiadas y ıı grabados; igualmente, ofreció al público el acre suplemento del número i6. Respecto a éste, la imprenta anunció en las páginas de la nueva publicación que, siendo constantes los pedidos que se le hacían sobre la reimpresión de dicho cuadernito, se había solicitado permiso a su dueño para expenderlo, y ya se vendía a real cada ejemplar y a peso la docena. ${ }^{174}$ Por otra parte, el hecho de que sólo circularan diecisiete números de La Prensa, y que no se anunciara la suspensión, sugiere que surgió algún imprevisto que interrumpió definitivamente la empresa.

Finalmente, se desconoce hasta cuándo permaneció Giménez en M éxico, y si el posterior regreso de Santa Anna al poder, en i853, le afectó, si es que acaso permanecía en el país. ${ }^{175}$

I7I. "Remitido", en El M onitor..., op. cit., 29 de enero de I85I, núm. 2078, p. I.

I72. Agradezco a M aría José Esparza el haberme informado de la existencia de un delgado volumen de dicho periódico en la Colección Alzate del Instituto de Investigaciones H istóricas. En la portada, realizada con letra manuscrita (muy probablemente del propio Giménez), se indica lo siguiente: "La Prensa, periódico hispano-mexicano publicado en M éxico por su único redactor $D$. Joaquín G iménez (EI Tío $N$ onilla) I85I". Se señala también que no se publicaron más números que los comprendidos en dicho tomo; éstos son apenas diecisiete. D esafortunadamente, los primeros fueron arrancados.

I73. "Anuncios. El T ío N onilla”, en La Prensa, 28 de enero de i85i, t. I, núm. I2. "AI M onitor Republicano", en El U niversal, 7 de agosto de 1849 , núm. 265, p. 2.

I74. "Anuncios", en La Prensa, 8 de febrero de i85i, t. I, núm. I7.

175. El hecho de que tanto el manuscrito "La H abana por dentro" (primera parte de su libro 
Por ahora no puede evaluarse más que parcialmente la importancia que tuvieron las caricaturas de EI T ío N onilla porque es poco lo que sabemos con respecto a dicho género y a su recepción durante la época. Publicaciones contemporáneas a la de Giménez, ahora perdidas, recurrieron también a la sátira política en imágenes; al menos $D$ on Juan Tenorio, periódico que estaba en contra de Arista, anunció hacia agosto de 1850 (antes de que El Tío $\mathrm{N}$ onilla iniciara su segunda época y con ella la publicación de las imágenes que conocemos) que iba a duplicar su tamaño y que engalanaría sus columnas con picantes caricaturas. ${ }^{176} \mathrm{~N}$ o obstante, se puede afirmar que la vieja tradición alegórica, preponderante en la gráfica satírica posindependentista poco a poco se iba diluyendo para dar paso a lo narrativo, apoyándose sin embargo en un simbolismo de vigencia efímera y momentánea, a veces muy difícil de descifrar por responder a coyunturas específicas, aunque se apoyaba también en estereotipos como el del maromero y el pancista, de los que los caricaturistas decimonónicos harían un uso más prolongado estableciendo con ello un repertorio común de símbolos que facilitaba a la vez la construcción y la decodificación de las imágenes.

Una gran riqueza cultural de la época se refleja en los escritos e imágenes de Joaquín Giménez, el Tío Nonilla; ellos son testimonio de un ingenio agudo, del cual, en este trabajo, sólo se han tocado algunos aspectos. Convendrá más adelante considerar el cruce de tradiciones tanto literarias como visuales que confluyeron en sus creaciones mexicanas. Será importante también intentar localizar, además de las caricaturas de la primera época de EI Tío N onilla, publicaciones como La Palanca, El H uracán, D on Juan Tenorio, etcétera, las cuales no sólo arrojarán mayor información sobre el periódico de Giménez, sino también sobre la historia de esos años, y en particular sobre la propia gráfica.

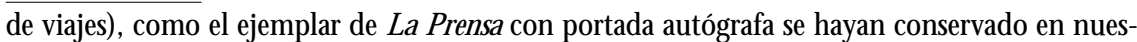
tro país sugieren la posibilidad de una salida precipitada de $M$ éxico en al gún momento.

176. El H onor, 6 de agosto de i85o, t. I, núm. I7, p. 4. Curiosamente, se anunció también que en la primera de las caricaturas de $D$ on Juan Tenorio se representaría "al poeta ayudante del $M$ ontecristo montado en el tomito de El grito de Dolores á modo de rocin y salmodiando con la lira en la mano una sentida plegaria en los yermos de Yucatán, á fin de obtener una modestisima silla curul en medio de los representantes de la nación". Se referían, según parece, a Juan M iguel de Losada, el poeta cubano que meses después retó a duelo a Giménez. Por otra parte, cabe señalar que Vicente Segura fue su redactor, según se aclara en "Sección asquerosa", en El Tío..., op. cit., suplemento del núm. 2 de El Tío..., op. cit., sin fecha, t. II, p. 7. 
En cuanto al aspecto meramente histórico, El Tío N onilla, en sus dos épocas, refleja muy bien el uso que los grupos y partidos políticos hicieron de la prensa a la cual financiaron. D urante su primera etapa, posiblemente pagada por Santa Anna, el periódico criticó al gobierno de Herrera (cuyo brazo derecho era Arista); en su segunda etapa, sus artículos y caricaturas criticaron al desterrado Santa Anna, a los partidarios de éste, a los conservadores, a algún liberal puro, y en general a todos los opositores de Arista, el ministro de Guerra, apoyándolo en su lucha por la silla presidencial durante ı85o.

Las inconsistencias de $G$ iménez fueron varias durante la primera época de El Tío N onilla: primero tomó una posición política de manera precipitada en un país desconocido; luego asumió una postura política contra la forma republicana, trabajando veladamente en favor de la dictadura, a pesar de declararse republicano; otra inconsistencia, probable, fue la de haber "coqueteado" desde entonces con Arista para sondear posibles beneficios. Durante la segunda época, a la vuelta de su destierro, sus incongruencias continuaron: en principio mintió ante la opinión pública (más que ante las autoridades, con las que probablemente ya estaba de acuerdo) en cuanto a que había empeñado su palabra de honor de no entrometerse en la política mexicana; en seguida dio un viraje político repentino del santanismo al moderantismo, que sus antiguos aliados atribuyeron al jugoso auspicio de Arista; finalmente, a pesar de que poseía una lengua incisiva, y de que presumía de estar dispuesto a batirse con los enemigos que lo criticaban, ${ }^{177}$ cuando llegó el momento de la confrontación se intimidó, primero ante la furia del diputado García y García, y luego ante la de Juan M iguel de Losada, quienes se consideraron calumniados por él.

Es muy probable que sobre todo haya sido el interés económico el que hizo que el desterrado periodista español escribiera y publicara caricaturas primero en favor de un bando y luego en favor de otro. D urante el siglo xix no fueron excepcionales las ambigüedades, las incongruencias, las contradicciones, los vaivenes, ni en la política ni en el periodismo de nuestro país. De ello son testimonio las acciones de mexicanos destacados y de personajes menores, y también las continuas alianzas y rupturas que establecieron entre

177. Al autor anónimo de un artículo que D on Juan T enorio publicó en su contra, Giménez le espetó que, cuando supiera de quién se trataba, se las vería con él a través de la pluma o de las armas (con pistolas, sables, palos, etcétera, o dándole una lección de esgrima). El M onitor..., op. cit., M éxico, I4 de junio de I850, año vi, núm. I858, p. 3. 
sí, durante la década del cuarenta, los grupos con posiciones políticas encontradas. El de Giménez no fue, por tanto, un caso aislado. En todo caso, fue un hombre que llegó a un país extraño sufriendo en carne propia el castigo político por parte del gobierno de su país natal. \$ 
DOI: http://dx.doi.org/10.22201/iie.18703062e.2000.76.1898

234

HELIA EMMA BONILLA REYNA

Bibliografía

Balbuena Prat, Ángel, H istoria de la literatura española, 8a. ed., Barcelona, Gustavo Gili, 1974, t. I.

Bailey, Joyce W adell, "The Penny Press", en Ron Tyler et al., Posada's M exico, W ashington, W ashington Library of Congress, 1979, I64 pp.

Cotner, Thomas Ewing, The M ilitary and Political Carer of J ose J oaquin de H errera, Austin, The U niversity of T exas Press, 1949, $336 \mathrm{pp}$.

Cowley, M . y D aniel P. M annix, H istoria de la trata de negros, M adrid, Alianza, 1968, 28I pp.

Dictionnaire des illustrateurs-I800-I9I4 (Illustrateurs, caricaturistes et affichistes), París, H ubschmid \& Bouret, I22I pp.

Díez-Echarri, Emiliano et al., $\mathrm{H}$ istoria general de la literatura española e hispanoamericana, $2 a$. ed., M adrid, Aguilar, 1979.

García Pimentel Ruiz, M aría D olores, "El U niversal frente a los Estados U nidos: I848-1855", tesis de licenciatura en $\mathrm{H}$ istoria, U niversidad $\mathrm{N}$ acional Autónoma de M éxico, Facultad de Filosofía y Letras, 1997, I64 pp.

Giménez, Joaquín, "La H abana por dentro", manuscrito concluido en La $\mathrm{H}$ abana el $\mathrm{I}^{0}$ de junio de $1849,242 \mathrm{pp}$.

González N avarro, M oisés, Anatomía del poder en M éxico (1848-1853), M éxico, El Colegio de M éxico, 1977, 498 pp.

Grandville, 0 tro mundo, Barcelona, H esperus, I988, p. xxix.

$\mathrm{H}$ ale, Charles A., El liberalismo mexicano en la época de M ora, roa. ed., M éxico, Siglo XXI, I994, $347 \mathrm{pp}$.

Lira, Andrés, Comunidades indígenas frente a la ciudad de M éxico: T enochtitlan y T latel olco, sus pueblos y barrios, I8I2-I9I9, Zamora, El Colegio de M éxico-El Colegio de M ichoacán, I986, 426 pp.

M usset, Alfred, Viaje a donde se os antoje, Barcelona, H esperus, 1987, I78 pp.

O lavarría y Ferrari, Enrique et al., M éxico a través de los siglos, M éxico, C umbre, I977, t. Iv: M éxico independiente.

Palacio Atard, Vicente, La España del siglo XıX: I808-I898, M adrid, Espasa-Calpe, I978, $668 \mathrm{pp}$.

Pérez Escamilla, Ricardo, "Arriba el telón. Los litógrafos mexicanos, vanguardia artística y política del siglo xIx", en M useo N acional de Arte, N ación de imágenes: La litografía mexicana del siglo XIx, M éxico, Amigos del M useo N acional de Arte-Instituto $\mathrm{N}$ acional de Bellas Artes-Grupo ICA-Banamex-Elek, M oreno Valle y Asociados, I994, p. 28.

Q uiñones, I sabel, M exicanos en su tinta: calendarios, M éxico, Instituto $\mathrm{N}$ acional de Antropología e H istoria, 1994 (Colección 0 bra D iversa), p. I25.

Romero de Terreros, M anuel (prólogo y selección), Poliantea: Conde de la Cortina, M éxico, U niversidad N acional Autónoma de M éxico, 1944 (Biblioteca del Estudiante U niversitario).

Rueda Smithers, Salvador, El diablo de Semana Santa. El discurso político y el orden social en la ciudad de M éxico en I850, M éxico, Instituto N acional de Antropología e H istoria, I99I (Colección Divulgación), 335 pp. 
DOI: http://dx.doi.org/10.22201/iie.18703062e.2000.76.1898

JOAQUÍN GIMÉNEZ Y EL TÍO NONILLA

Vázquez M antecón, Carmen, Santa Anna y la encrucijada del Estado. La dictadura (1853-1855), M éxico, Fondo de Cultura Económica, 1986, 313 pp.

Zamacois, $\mathrm{N}$ iceto de, $\mathrm{H}$ istoria de $\mathrm{M}$ éjico desde sus tiempos más remotos hasta nuestros días, Barcelona-M éxico, J. F. Parres, I88o, vol. XIII.

\section{H emerografía}

Anónimo, Antonio López de Santa Anna / Candidato para la próxima presidencia, M éxico, imprenta de Vicente G. Torres, en el ex convento del Espíritu Santo, I850.

Gacetilla del M onitor, M éxico, $\mathrm{I}^{0}$ de agosto de i85o, t. I, núm. 3.

Gómez $\mathrm{H}$ aro, Eduardo, "Por qué fue expulsado del país el redactor de El Tío N onilla", en Revista de Revistas, M éxico, enero-abril de I925, año xvi, núm. 775, p. 29.

Junguito, Rafael, Contestación al alegato presentado por D. Juan Suárez de N avarro en la causa instruida al teniente coronel $D$. Rafael Junguito, por difamación, M éxico, Imprenta de Vicente G arcía T orres, a cargo de L. Vidaurri, I850.

El M onitor Republicano, M éxico, del 4 de agosto al 3 I de diciembre de 1849 , año 5, núms. I544 al 1693.

El M onitor Republicano, M éxico, del I $^{0}$ de enero al 3i de diciembre de i849, año vi, núms. I694 al 2047.

El M onitor Republicano, M éxico, del $\mathrm{I}^{0}$ de enero al 2I de enero de I85I, año viI, núms. 2048 al 2068.

El Siglo Diez y N ueve, M éxico, I4 de diciembre de ı849, t. II, núm. 348.

El Tío N onilla, M éxico, del in de agosto de 1849 al I7 de febrero de I850, t. I, núms. i al 26.

El Tío N onilla, M éxico, del 29 de agosto al 26 de diciembre de i850, t. II, núms. I al i7.

EI U niversal, M éxico, 7 de agosto de i849, t. II, núm. 265. 